\title{
Driving mechanisms of Holocene lagoon development and barrier accretion in Northern Elis, Peloponnese, inferred from the sedimentary record of the Kotychi Lagoon
}

\author{
Elke Haenssler, Ingmar Unkel, Walter Dörfler, Marie-Josée Nadeau
}

How to cite:

Abstract:

Keywords:
Haenssler, E., Unkel, I., Dörfler, W. ひ NAdEAU, M.-J. (2014): Driving mechanisms of Holocene lagoon development and barrier accretion in Northern Elis, Peloponnese, inferred from the sedimentary record of the Kotychi Lagoon. - E\&G Quaternary Science Journal, 63 (1): 60-77. DOI: 10.3285/eg.63.1.04
Kurzfassung

Addresses of authors: Elke Haenssler, Ingmar Unkel* ${ }^{*}$ Institute for Ecosystem Research, Kiel University, Olshausenstr. 75, 24118 Kiel, Germany. Walter Dörfler, Institute for Pre- and Proto-history, Kiel University, Johanna-Mestorf-Straße 2-6, 24118 Kiel, Germany. Marie-Josée Nadeau, Leibniz-Laboratory for Radiometric Dating and Isotope Research, Max-Eyth-Str. 11-13, 24118 Kiel, Germany. All authors, Graduate School “Human Development in Landscapes”, Kiel University, Leibnizstr. 3, 24118 Kiel, Germany. corresponding author E-mail: iunkel@ecology.uni-kiel.de, Phone: +49 431 880-5241

\section{Introduction}

Situated at the dynamic interface between land and sea, coasts are transient landscapes shaped by the interplay between macroscale (sea-level changes, climate, and tectonic stability) and microscale processes (sediment supply, topographical inheritance, wave energy, and tidal range (BAO et al., 2007)). Any change in the power of these controlling factors directly translates into morphological adjustment of the coast (COOPER, 1994; BAO et al., 2007). Where rivers enter the sea, hinterland sediment supply associated with natural climate fluctuations or anthropogenic activity provides a significant contribution to the gross sediment budget and thus forms the coast. If the rate of sediments supplied by rivers exceeds the combined ability of waves and tides to carry away the sediment, a delta forms at the mouth of the river. Delivered to the delta front, sediments may be re-deposited to block the river mouth and shape the coast by forming 
barriers, lagoons or marshes (McMAnUs, 2002; KRAFT et al., 2005; Dinis et al., 2006). In this context, sea level has an exceptional role as it serves as the ultimate base level (PLATER \& KIRBY, 2011).

During the Holocene, sea level exhibited significant fluctuations, mostly responding to the advance and retreat of the continental ice sheets (LAMBECK et al., 2010). In general, two distinct periods of sea level rise can be distinguished. An early period of rapid sea level rise spanning from 18000 to $6000 \mathrm{BP}$ contrasts with a period of near stability from 6000 $\mathrm{BP}$ to the present. During the early phase, coastal evolution was predominantly controlled by the post-glacial sea-level, while by $6000 \mathrm{BP}$ local and regional factors (isostasy, subsidence, sediment supply, anthropic activity) overwhelmed the power of attenuated sea level rise (BAO, FreITAS \& ANDRADE, 1999; Freitas et al., 2003; Dinis et al., 2006). This mid-Holocene sea level stabilization had major influence on fluvial sedimentation in coastal regions and triggering delta progradation on a global scale (STANLEY \& WARNE, 1993). The formation of many Mediterranean lagoons for example on the Thessaloniki plain, Greece (FouAche et al., 2008), on the Iberian Peninsula (Freitas et al., 2003; BAo et al., 2007; Costas et al., 2009), at the coastal plain of Marathon, Greece (PAvlopoulos et al., 2006) or on the northern Peloponnese, Greece (Kontopoulos \& Avramidis, 2003) can be traced back to this period.

To understand coastal evolution and the driving mechanism, the sedimentary record of lagoons has great potential. As a net area of deposition, lagoons preserve the sedimentary signature of multiple processes acting upon the coastline and thus offer the possibility to trace spatio-temporal coastline migration and its causes.

The present study addresses the Holocene coastal evolution of the northern Elis, Northwest Peloponnese, Greece. It focuses on the coastal stripe between the limestone headlands of the Mavra Vouna (Black Mountains) in the north and Cape Kyllini in the south both connected by a crescentic beach isolating a coast parallel sequence of lagoons and marshes (Fig. 1). Out of these lagoons, the Kotychi Lagoon, serves as a geoarchive. Previous studies indicate a series of lagoons fringing the Elean coast for at least 7000 years (Kraft et al., 2005; Kontopoulos \& Koutsios, 2010). However, there is no evidence about the onset of barrier-lagoon accretion in Elis. Research at the Elian coast extends back to RAPHAEL $(1973,1978)$ who combined geomorphological and archaeological evidence to identify cycles of coastal pro- and retrogradation from the late Holocene until Turkish Times. Likewise, a synthesis of geomorphology, literary sources and drill cores allowed KRAFT et al. (2005) to reconstruct midHolocene evolution of the Elean coastline. The authors identified a sequence of ancient lagoons and barrier islands resulting from the interplay of varying sediment fluxes and sea level rise. Recent studies at the Kotychi Lagoon focused on a local palaeogeographic reconstruction by pollen analyses of sediment cores (LAzArova, Koutsios, \& Kontopoulos, 2012) and the analysis of microfossil assemblage and sedimentology (Kontopoulos \& Koutsios, 2010).

The aim of this study is to decipher coastal morphogenesis of northern coastal Elis during the Holocene and to put the evolution into a general, circum Mediterranean context. Special emphasis is placed on the driving mechanisms of coastal evolution and the role of post glacial sea level rise as one potential driver of change. In order to achieve these aims, high resolution XRF-data is combined with grain size and $\mathrm{C} / \mathrm{N}$ analyses from a sediment core retrieved at the shore of the Kotychi Lagoon. As XRF-analysis is mostly applied to limnic or deep sea environments, this study is one of few using XRF-data to reconstruct coastline evolution.

\section{Regional Setting \\ 2.1 Geography and Geology}

The study area comprises a coastal stripe in the northwestern part of the Peloponnese, which belongs to the northern part of the prefecture of Elis (Fig. 1).

The convergence of the African and the Eurasian plate which culminated in the Alpine orogeny is crucial for present geology and tectonic activity in the western Peloponnese because geological basement and major fault systems are related to this compressional regime. Located in the direct vicinity to the Hellenic arc, the center of subduction since Miocene times (23-7 Ma BP), the study area is part of one of the most tectonically and seismically active regions in Greece (Fountoulis et al., 2011). A detailed earthquake catalogue spanning the twentieth century is summarized by Burtona et al. (2004). In the study area, Miocene diapirism caused by Triassic evaporates of the Alpine basement contributes to complicated tectonic deformation and high seismicity (UNDERHILL, 1988; MAROUKIAN et al., 2000). According to Fountoulis et al. (2011), major faults form neotectonic blocks which exhibit diverging trends of vertical movement. While uplift rates between 0.16 and $0.67 \mathrm{~mm} /$ year characterize the hinterland, the coastal strip is subsiding (Fountoulis et al., 2011).

The area is characterized by a broad coastal plain where the limestone headlands of Cape Kyllini, Cape Kunupeli and the Mavra Vouna are the only relicts of the Alpine formations. They comprise series of white to light brown limestones (geological map of Greece, sheet Amalias, sheet Nea Manolas, scale 1:50,000, IGME (1977); Jacobshagen, 1986). Further remains of the alpine basement in this area are covered by Neogene to Pleistocene marine sandstones, sandy clays and clayey marls which intercalate with Holocene terrestrial and torrential clayey and sandy deposits to the east (geological map of Greece, sheet Amalias, sheet Nea Manolas, scale 1:50,000, IGME (1977); JACOBSHAGEN, 1986; MAROUKIAN et al., 2000). The latter represent the most extensive Quaternary alluvial deposits in the Peloponnese (RAPHAEL, 1978; Poulos et al., 2002). Primarily responsible for the accumulation of these deposits is the Peneus River, originating to the east in the Arcadian Mountains and currently entering the Ionian Sea south of Cape Kyllini. However, the palaeo-delta of the Peneus River is believed to have been located north of Cape Kyllini giving rise to a sequence of lagoons and marshes embedded in the prograding delta and fed by sediments from the Elean uplands. As a relic of this past river course, a system of ancient levees depicted in historic maps (cf. CurTius, 1851) has been detected a few kilometers south of the Kotychi Lagoon (Fig. 1) (PhILIPPSON, 1959; RAPHAEL, 1978; Kraft et al., 2005; Fountoulis et al., 2011). An anthropogenic or natural (tectonic) diversion of the Peneus River is still subject of discussion but is believed 


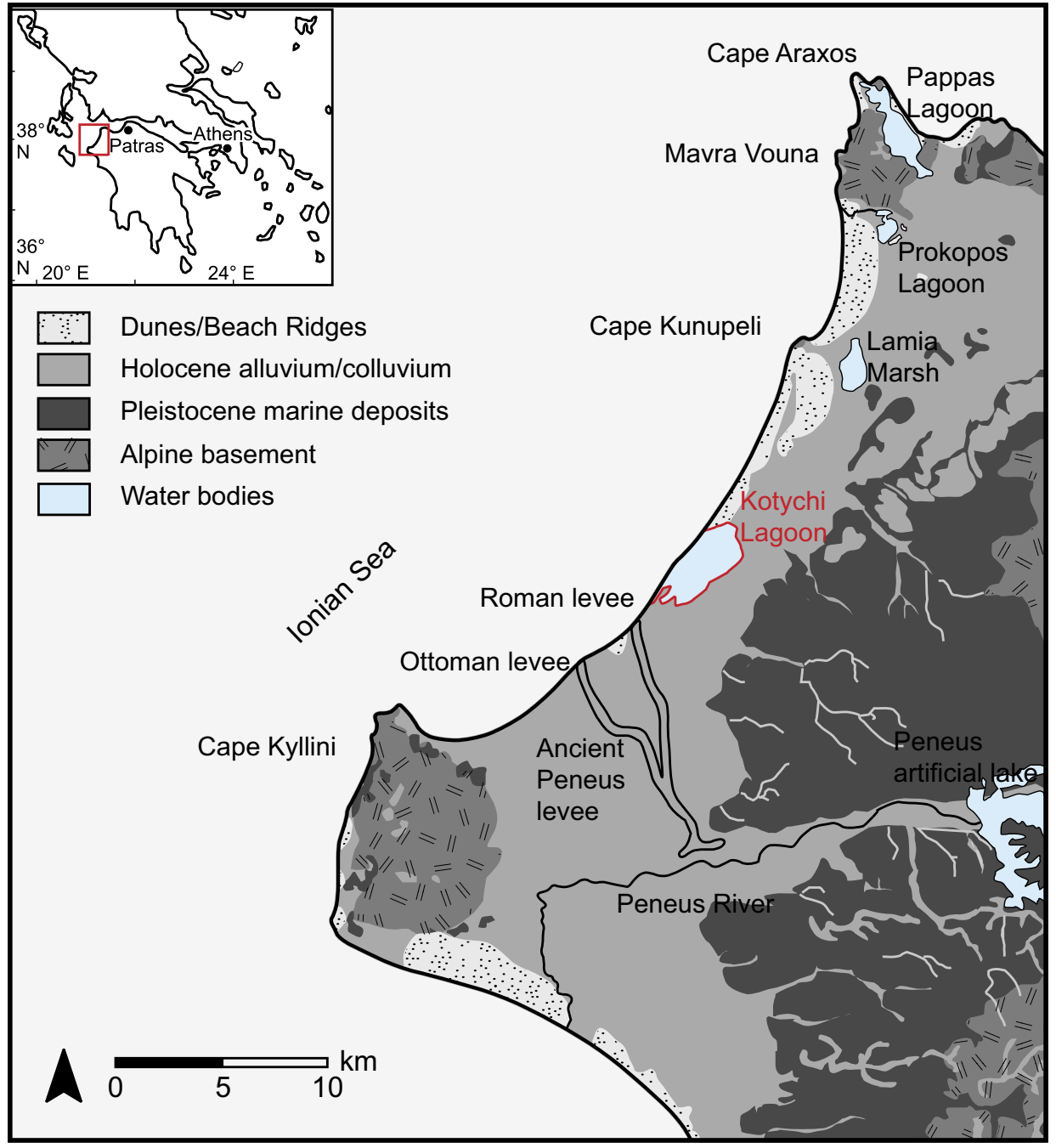

Fig. 1: The study area (modified after FounTOULIS et al., 2011).

Abb. 1: Das Untersuchungsgebiet (nach Fountoulis et al., 2011, verändert). to have occurred in the 17th century AD (KRAFT et al., 2005; Kontopoulos \& Koutsios, 2010; Fountoulis et al., 2011). Starved of its sediment supply, erosion has dominated the north Elean ever since (KRAFT et al., 2005).

The high seismicity accompanied by gradual as well as episodically crustal displacement limits the utilization of a uniform sea level curve. The relative sea level data for the Elis coastal plain varied between $0.5 \mathrm{~m} / \mathrm{ka}$ (VÖTT, 2007) and $0.95 \mathrm{~m} / \mathrm{ka}$ (Kontopoulos \& Koutsios, 2010) from approximately $5000 \mathrm{cal} \mathrm{BC}$ to roughly $1000 \mathrm{cal} \mathrm{BC}$ and since then, increased to values of $0.7 \mathrm{~m} / \mathrm{ka}$ (VӧтT, 2007) up to $1.2 \mathrm{~m} / \mathrm{ka}$ (Kontopoulos \& Koutsios, 2010).

\subsection{Lagoonal settings}

As part of the coastal lagoon barrier accretions plain which characterizes the NW part of the Peloponnese, the Kotychi Lagoon is believed to have formed in the prograding delta of the Palaeo-Peneus River more than 7000 years ago (KRAFT et al., 2005; Kontopoulos \& Koutsios, 2010). The lagoon is bound to a gentle basin structure (Avramidis pers. comm.) and is separated from the wave dominated and microtidal coast of the Ionian Sea by a low relief barrier, dissected by a small channel. On the eastern, landward shore, small deltas prograde into the lagoon and intertidal/supratidal mud flats covered with halophytic vegetation are prevailing (Fig. 2) (Avramidis et al., 2008; LAzArova, Koutsios, \& Kontopou-
LOS, 2012). With a maximum depth of $2.5 \mathrm{~m}$ and an average depth of $0.5 \mathrm{~m}$ the Kotychi Lagoon is considerably shallow (Kontopoulos $\&$ Koutsios, 2010). During the wet season in winter, salinity values range from $8 \%$ and $17 \%$, whereas during the dry summer month, restricted runoff and enhanced evaporation lead to salinity from $20 \%$ to $37 \%$ (KoNTopoulos \& Koutsios, 2010). Six main streams and a few torrential rivers mostly originating in the foothills of the Arcadian Mountains characterize the hydrological network. Fluvial sediments supplied by the streams are the major constituent of sediments deposited in the lagoon whereas autochthonous shell fragments are of minor importance. Aeolian sands, suspended sands eroded on tidal flats, or sand washed into the lagoon by washover fans are negligible (AvRAMIDIs et al., 2008). The torrential discharge regime of the rivers results in a seasonal expansion of the water body between 710 and 850 ha (DoukAKIS, 2003).

\subsection{Climate}

Meteorological data from the nearby Araxos station $\left(38^{\circ} 08 \mathrm{~N} / 21^{\circ} 23.5 \mathrm{E} ; 12 \mathrm{~m}\right.$ above sea level) reflects a typical Mediterranean climate. In the period from 1965 to 2003, the mean annual temperature was $17.8{ }^{\circ} \mathrm{C}$ with a relative humidity of $69.4 \%$. The mean annual precipitation between 1948 and 2007 was $669 \mathrm{~mm}$ with a pronounced winter maximum between September/October and March/April. This season- 

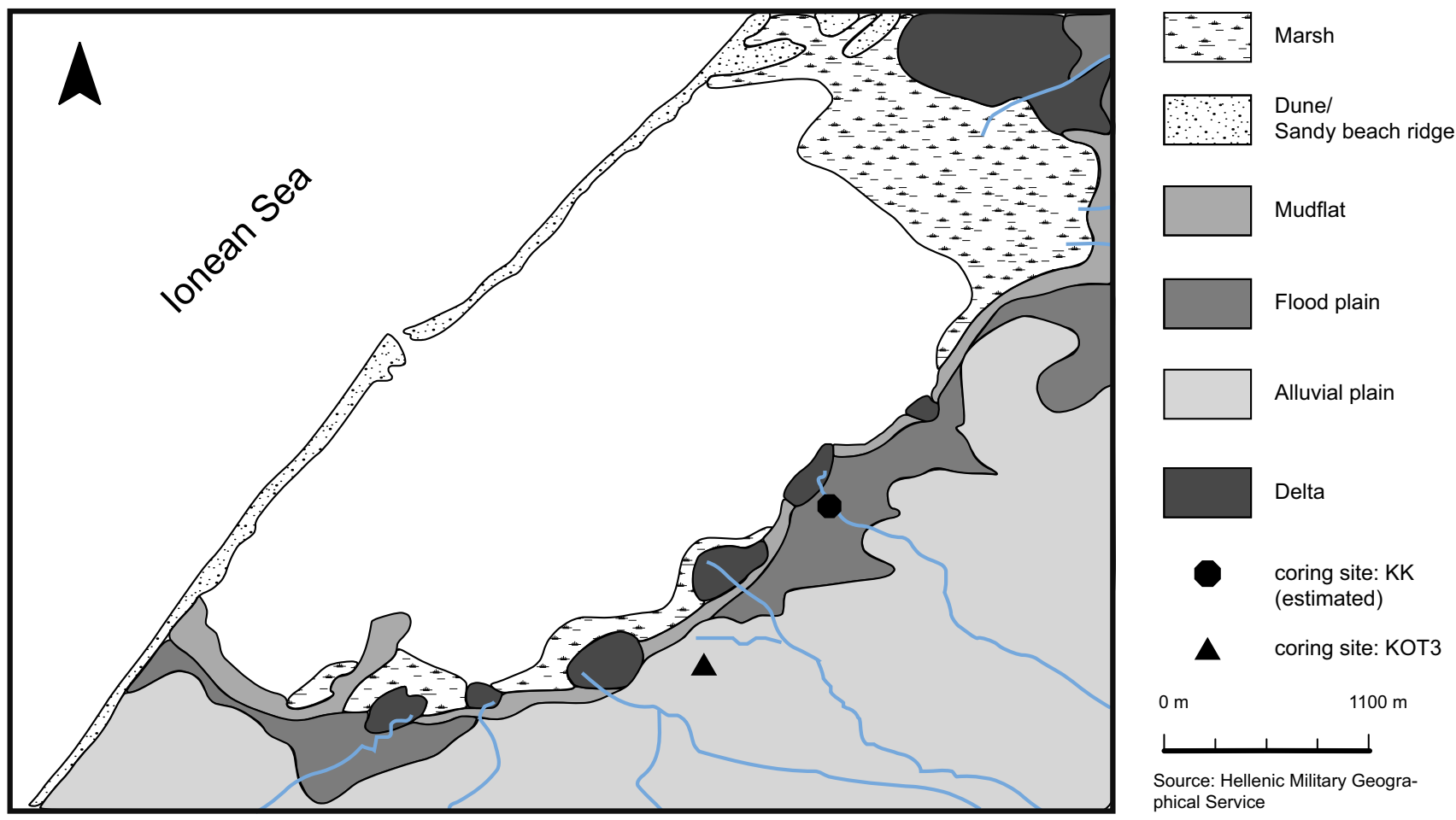

Fig. 2: Lagoonal settings (modified after AVRAMIDIs et al., 2008).

Abb. 2: Die Kotychi Lagune (nach AVRAMIDIS et al., 2008, verändert).

ality is reflected by cyclic sediment fluxes within the year. They are highest at the beginning of the wet season removing easily erodible soils barely vegetated and desiccated during the summer (Poulos et al., 2002).

\section{Material and Methods 3.1 Field and Laboratory Methods}

In April 2011, the two parallel sediment cores KOT3A and KOT3B ( $37^{\circ} 59,752 \mathrm{~N} / 21^{\circ} 18,133 \mathrm{E}$, Fig. 2$)$ were retrieved on the alluvial plain at the eastern shore of the Kotychi Lagoon using a high-precision rod-operated piston corer (UsingerSystem) (Mingram et al., 2007). With a total length of 980 $\mathrm{cm}$, KOT3A comprises 10 segments each approximately one meter in length.

The sediments in the uppermost centimeter of each core segment might be disturbed during the coring process, which introduces gaps to the sedimentary sequence. Further, a sand layer in KOT3A at depth from 85 to $123 \mathrm{~cm}$ could not be recovered. To overcome these gaps, the parallel core KOT3B comprising $940 \mathrm{~cm}$ split into 10 segments was retrieved in a distance of about $2 \mathrm{~m}$ from KOT3A.

All sediment cores were transported to Kiel University in densely packed plastic inliners, where they were opened, split lengthwise in the lab and stored in a core repository at $4{ }^{\circ} \mathrm{C}$. One half of each core was used for non-destructive scanning methods and subsequently archived. The other half of the core served for different material-consuming analyses such as grain size analysis and $\mathrm{CN}$-analysis.

Prior to any analytical procedures, macroscopic components, sediment structures and sediment texture were documented on split and cleaned sediment surfaces. Sediment color was determined according to Munsell Soil Color Charts.
The archive halves of all cores were scanned at $1 \mathrm{~cm}$ resolution for major elements with an Avaatech X-ray Fluorescence (XRF) core scanner equipped with a Rhodium tube (Richter et al., 2006). The results of the scans are displayed as element counts per seconds (cps) at each measuring point. For elements with lower atomic number (Al, Si, P, S, Cl, K, $\mathrm{Ca}, \mathrm{Ti}, \mathrm{Mn}, \mathrm{Fe}$ ) generator settings of $10 \mathrm{kV}$ and $1000 \mu \mathrm{A}$ with an exposure time of 10 seconds were used. For elements with higher atomic number $(\mathrm{Br}, \mathrm{Rb}, \mathrm{Sr}, \mathrm{Zr})$ setting of $30 \mathrm{kV}$ and $2000 \mu \mathrm{A}$ with an exposure time of 20 second were chosen. At each measuring point, element counts were normalized to the total element counts (cf. Cuven, Francus \& LAmouREUX, 2011) to avoid possible bias caused by non-linear absorption (matrix effects) or by dilution of elements outside the measuring range of the spectrometer (closed-sum effect) (Richter et al., 2006; LöWEMArk et al., 2011; Cuven, FranCus \& LAmoureux, 2011). Furthermore, ratios of selected elements were established and used as geochemical proxies (cf. chapter 6.1).

The XRF-data was used to support the visual correlation of the parallel cores KOT3A and KOT3B. By matching distinct peaks in both core profiles, the respective gaps of $\mathrm{KO}$ T3A could be completed with data from KOT3B to obtain the continuous, undisturbed sedimentary sequence KOT3. Due to inhomogeneous sediment surface with abundant sharp shells, XRF-scanning between 313 and $330 \mathrm{~cm}$ was not possible. Hence, this section was excluded from further interpretation.

To assess the degree of association between chemical elements, Pearson's correlation coefficients were calculated for the major elements and plotted in a correlation matrix (Fig. 4) using the corrgram package in the statistics software R version 2.13.2 (R Development CoRe TeAm, 2011; Wright, 2011). A strong positive correlation between chemical ele- 
ments suggests a common driving force whereas negative values imply an inverse association of elements.

All samples for destructive analyses were solely extracted from KOT3A.

The concentrations of total nitrogen (TN), total organic carbon (TOC) and inorganic carbon (IC) were determined on 86 dried, grinded and homogenized samples through combustion in an elemental analyzer (Euro EA, Elementanalyzer). To quantify the relative abundance of terrestrially and aquatically organic matter $\mathrm{C} / \mathrm{N}$ (TOC/TN) ratios were calculated (Meyers \& LALLIER-VERGÈs, 1999).

The grain size distribution of the sediments $<1.8 \mathrm{~mm}$ was determined using a laser-particle-analyzer (Mastersizer 2000, Malvern). 78 samples ( $\sim 0.5 \mathrm{~g}$ ) were taken and successively treated with Hydrogen Peroxide until all organics were removed. Prior to measurements, rinsed samples were suspended in $10 \mathrm{ml}$ of distilled water and $0.5 \mathrm{ml} 0.1 \mathrm{M}$ Sodium Pyrophosphat to prevent coagulation. Final grain-size distribution/histograms is the mean of 12 runs with a measuring time of 60 seconds for each sample run.

\subsection{Proxy Interpretation}

Depending on the environmental conditions in a water body or its catchment, geochemical and sedimentological proxies can be interpreted in multiple ways. The grain size distribution in limnic or lagoonal sediments is an indicator for horizontal as well as vertical distance to the shoreline and hence water level fluctuations. In close proximity to the shoreline a greater proportion of coarse grains is deposited while the amount of fine sediments increase with vertical transport distance to the shoreline (BURNETT et al., 2011). However, the grain size distribution can also be a signal of catchment erosion, either reflecting shifts from mainly physical to more chemical weathering or enhanced precipitation and depositions of coarse sediments (KoINING et al., 2003).

In lagoonal systems, organic matter is a binary mixture of terrestrial and aquatic sources. The origin of organic matter can be distinguished by a characteristic $\mathrm{C} / \mathrm{N}$-ratio. Aquatic organic matter generally has $\mathrm{C} / \mathrm{N}$-ratios between 4 and 10 in contrast to cellulose-rich and protein-poor vascular land plants which have $\mathrm{C} / \mathrm{N}$-ratios higher than 20 (MEYERs \& LALLIER-VERGÈs, 1999; BERTRAND et al., 2010). Understanding the temporal changes in the origin of sedimentary organic matter may help identifying periods of enhanced terrestrial input versus autochthonous algal productivity, which in turn sheds light on palaeoenvironmental conditions.

Chemical elements may play various roles within an ecosystem. In near coastal environments, $\mathrm{Br}$ and $\mathrm{Cl}$ act as geochemical markers that record marine influence. Diverging elemental profiles observed in the sedimentary record can result from a large affinity of $\mathrm{Br}$ to organic compounds or from a terrestrial source of $\mathrm{Cl}$ as a common constituent of sedimentary rocks (BOYLE, 2001; SCHOFIELD et al., 2010).

It is assumed that the amount of $\mathrm{Ca}$ and $\mathrm{Sr}$ represents the carbonate fraction which can have both an allochthnous as well as an authochthonous origin (COHEN, 2003). Authochthonous carbonate precipitation with co-precipitation of Sr$\mathrm{CO}_{3}$ occurs during the summer months when the water is saturated with respect to carbonate due to increased evaporation accompanied by lake level fluctuation and/or algal photosynthesis in the epilimnion (COHEN, 2003). When the relationship between $\mathrm{Ca}$ and $\mathrm{Sr}$ is out of phase and one, or both chemical profiles follow the immobile, clastic fraction, the detrital contribution controlled by weathering in the catchment must be considered (LAST, 1994; COHEN, 2003). A likely source for Sr may be silicates, particularly plagioclase feldspars (Kylander et al., 2011). To assess the amount of detrital and biogenic carbonate the $\mathrm{Ca} / \mathrm{Sr}$ ratio can be used. Biogenic calcite precipitated from microorganism is more enriched in Sr than inorganically precipitated calicit/dolomite. Thus, $\mathrm{Ca} / \mathrm{Sr}$ is high when the contribution of detrital carbonate is elevated and the biogenic component is low (Hodell et al., 2008). To visualize layers rich in biogenic carbonate, opposed to those composed of detrital silicate minerals, the $\mathrm{Si} / \mathrm{Sr}$ ration is common tool. The presence of detrital rich layers is inferred from a high $\mathrm{Si} / \mathrm{Sr}$ (Hodell et al., 2008).

The amount of clastic material in the sediment is generally inferred from the signal of $\mathrm{Al}, \mathrm{Si}, \mathrm{K}, \mathrm{Ti}, \mathrm{Fe}, \mathrm{Rb}$ and $\mathrm{Zr}$ reflecting weathering, runoff, erosion, and/or aeolian activity within the catchment (MüGLER et al., 2010). However, diverging chemical profiles of the clastic elements may be the response of superimposing signals. Si, for example, has a detrital component representing aluminosilicate minerals but also has an autochthon biogenic component influenced by the abundance of diatom frustuls (KYLANDER et al., 2011.). Some chemical proxies are strongly correlated with the grain size of clastic sediments. $\mathrm{Ti}, \mathrm{Rb}$ and $\mathrm{K}$ are usually concentrated in clay minerals and mica, while the distribution of $\mathrm{Zr}$ and $\mathrm{Si}$ is linked to their association with the medium to coarse silt fraction (KoINING et al., 2003; KYLANDER et al., 2011). Hence, sorting during sedimentation has an influence on the chemical record and the $\mathrm{Zr} / \mathrm{Rb}$ ratio is often used as a proxy for changes in grain size distribution. Lower values point to fine-grained sediments rich in Rb while higher values indicating coarse-grained material rich in Zr (DYPVIK \& HARRIS, 2001).

$\mathrm{Mn}$ and Fe both have an exceptional position. They are associated with the lithogenic fraction but unlike the stable, immobile components, their concentration is strongly controlled by redox remobilization. Under anoxic conditions, the reduced, mobilized $\mathrm{Fe}^{2+}$ is less stable in the water column than $\mathrm{Mn}^{2+}$ and may re-precipitate as $\mathrm{FeCO}_{3}$ or more frequently as FeS. Hence, during periods of anoxia $\mathrm{Mn} / \mathrm{Fe}$ ratio is low. $\mathrm{Mn}^{2+}$ will primarily precipitate as $\mathrm{MnCO}_{3}$ and hence, the reaction is strongly $\mathrm{pH}$-dependent and will most likely occur under anoxic conditions with high $\mathrm{pH}$ (EUSTERHUES et al., 2002; KoINING et al., 2003).

When associated with $\mathrm{Fe}, \mathrm{S}$ may also indicate anoxic conditions but generally, it is present in inorganic S-complexes reacting with organic matter and therefore, reflects the organic content of sediments. S-retention can also be linked to gypsum deposition when correlated with Ca (CoHEN, 2003; STRIEWSKI et al., 2009).

\section{Chronology}

Two bulk samples and three shell samples from KOT3A were processed and radiocarbon dated at the Leibniz Laboratory, Kiel, Germany (Tab. 1). To minimize the risk of dating redeposited shells, only intact valves in growth position were sampled. Another four ${ }^{14} \mathrm{C}$ samples dated at Beta Analytics 
were available from the core KK retrieved in the direct vicinity of KOT3 by Kontopoulos and Koutsios (2010). The five samples from KOT3 taken in between 318 and $908 \mathrm{~cm}$ below sediment surface (b.s.s.) cover an age range of 4500-19900 ${ }^{14} \mathrm{C}$-years uncalibrated.

The four shell-samples from the core KK were taken between 355.5 and $737 \mathrm{~cm}$ b.s.s. providing ages in stratigraphical order between 2800 and $6400{ }^{14} \mathrm{C}$-years uncalibrated.

While the shell samples of KOT3 are in good stratigraphical agreement with the previously published ages from KK, the bulk samples (KIA45677 and KIA45678, Tab. 1) appear to be unusually old.

Most likely, the two bulk samples contain a considerable amount of re-worked, old carbon, derived from the catchment of the lagoon. Hence, the two bulk samples were treated as outliers (BRONK RAMSEY, 2009) and only the shell samples were included in the age depth model.

As neither shell samples nor macro-remains could be retrieved from KOT3 below $375 \mathrm{~cm}$, the two lowermost ${ }^{14} \mathrm{C}$ dates of the core KK (Beta-194653 and Beta-194654, Tab.1) were included in the age depth model to build a chronology for the entire sedimentary sequence. Based on the lithology, it is assumed that the lower part of both cores was deposited simultaneously under the same lagoonal conditions, while the cores show a different sedimentary evolution in the upper part, which is strongly influenced by fluvial processes such as channel formation.

All ${ }^{14} \mathrm{C}$ ages were calibrated using Oxcal 4.1. (BRONK RAMSEY, 2001, 2008, 2009) with respect to the IntCal04 calibration curve (REIMER et al., 2004) and are reported with a 1-sigma $(68.2 \%)$ probability range. Calibrated years are denoted as "cal BP" (before AD 1950) according to Mook \& VAN DER Plicht (1999). For all samples a marine/brackish environment was assumed and a marine reservoir correction of $390 \pm 85 \mathrm{BP}$ as suggested by SIANI et al. (2000) was applied. An age-depth-model based on 5 shell samples from KOT3 and KK was calculated applying the P-Sequence model of $\mathrm{OxCal}$, which assumes random deposition (BRONK RAMSEY, 2008). The resulting age-depth polygon was directly extracted from Oxcal, returning maximal and minimal ages for every centimeter (Fig.3). A curve based on mean age values - $\left(\operatorname{age}_{\max }+\operatorname{age}_{\min }\right) / 2$ - was then used to plot the proxy data.

While the GPS coordinates of the two core sites are known, the exact elevation above sea level could not be determined for neither site. Thus, correlating the depths of the respective ${ }^{14} \mathrm{C}$ samples introduces an additional uncertainty to the age-depth-model. Due to all these challenges in dating, the paper aims at a general chronological context and ages reported here are rounded to the nearest hundred.

\section{Results 5.1 Lithology}

Based on sediment color, grains size distribution, and distinct changes in geochemistry, the sediment core KOT3 is subdivided into 16 units. A detailed description is presented in table 2 .

On average, the sedimentation rate is around $0.17 \mathrm{~cm} / \mathrm{a}$ with a maximum of $0.2 \mathrm{~cm} / \mathrm{a}$ and a minimum of $0.02 \mathrm{~cm} / \mathrm{a}$. As the age-dept-model and thus the sedimentation rate is result of a core synthesis, only average rates are given.

Tab. 1: List of radiocarbon samples taken from KOT3 and KK (Kotihi 2-8) (KonTOPOULOS హ KoutsIOS, 2010) from the Kotychi Lagoon.

b.s.s. = below sediment surface .

* $\quad$ = ages in cal BP, based on REIMER et al. (2004).

** = samples integrated in the OxCal-Model, calibrated using OxCal 4.1. Ages are in $1 \sigma$ range. For all samples a marine reservoir correction of $390+/-$ 85 a, based on SIANI et al. (2000) was applied.

Samples from KK are published in KonTOPOULOS \& KouTSIOS (2010).

Tab. 1: Liste der Radiokarbon-Alter von KOT3 und KK (Kotihi 2-8) (KonTopoulos \& Koutsios, 2010) von der Kotychi Lagune.

b.s.s. = below sediment surface (unterhalb der Sedimentoberfläche)

* $\quad$ = Alter in cal BP, nach REIMER et al. (2004).

** = Radiokarbon-Proben die in das OxCal-Modell integriert wurden. Alter wurden mit OxCal 4.1 kalibriert und sind im $1 \sigma-B e r e i c h$ angegeben. Eine Reservoir-Korrektur nach SIANI et al. (2000) von 390 +/- 85 Jahren wurde für alle Proben vorgenommen. Radionkarbon-Alter vom Kern KK sind in KoNTOPOULOS \& KoutSIOS (2010) publiziert.

\begin{tabular}{|c|c|c|c|c|c|c|}
\hline sample No. & $\begin{array}{c}\text { analysis } \\
\text { No. }\end{array}$ & sample material & ${ }^{14} \mathrm{C}$ age $[\mathrm{BP}]$ & $1 \sigma$ error $[B P]$ & IntCal04* & $\begin{array}{c}\text { depth } \\
\text { [cm b.s.s.] }\end{array}$ \\
\hline КОТЗАЗ18** & KIA48442 & Spisula sp. valve & 4625 & 40 & $4880-4790$ & 318 \\
\hline КОТЗАЗ55** & KIA48443 & Spisula sp. valve & 5140 & 40 & $5130-5050$ & 355 \\
\hline КОТЗАЗ75** & KIA48444 & Cerastoderma valve & 5285 & 40 & $5230-5160$ & 375 \\
\hline КОТЗ-565 & KIA45677 & Bulk sample & 11330 & 50 & $12940-12770$ & 565 \\
\hline К0Т3-908 & KIA45678 & Bulk sample & 19930 & 100 & 23680-23300 & 908 \\
\hline Kotihi 2 & Beta-194651 & Cerastoderma valve & 2830 & 40 & $2690-2500$ & 355.5 \\
\hline Kotihi 4 & Beta-194652 & Cerastoderma valve & 3860 & 40 & $3990-3780$ & 397.80 \\
\hline Kotihi 6** & Beta-194653 & Cerastoderma valve & 5490 & 40 & $6360-6250$ & 604.80 \\
\hline Kotihi $8 * *$ & Beta-194654 & Cerastoderma valve & 6410 & 40 & 7110-6960 & 737.00 \\
\hline
\end{tabular}


Tab. 2: Summarized lithostratigraphy of KOT3. Fig. 3 is the graphical version of this table. UB = upper boundary.

Tab. 2: Zusammengefasste Lithostratigraphie von KOT3. Abb. 3 ist die graphische Version der Tabelle. UB = upper boundary (obere Grenze).

\begin{tabular}{|c|c|c|}
\hline Unit \# & Depth [cm] & Lithologic description \\
\hline 16 & $0-73$ & $\begin{array}{l}\text { Recent soil, very dark brown }[10 Y R 2 / 1] \text { at the top to yellowish brown }[10 \mathrm{YR} 5 / 4] \text { at the medium sandy bottom, finer } \\
\text { layer with charcoal between } 68-73 \text {, edgy chert fragments, few snails }\end{array}$ \\
\hline 15 & $73-85$ & Sandy clayey silt coarsening upward, brown [10YR3/4], gravel at the top, few charcoal fragments, UB: sharp \\
\hline 14 & $85-123$ & Core loss \\
\hline 13 & $138-179$ & $\begin{array}{l}\text { Clayey silt, greenish grey [Gley2 5/10G] with abundant yellowish brown [10YR 5/6] striae almost entirely brown [10YR } \\
\text { 4/3] at the top, intercalated silt layers [cm-mm scale], charcoal-rich at the top [123-138], UB: sharp }\end{array}$ \\
\hline 12c & $179-197$ & $\begin{array}{l}\text { Strong clayey silt, greenish grey [Gley2 5/10G] with abundant yellowish brown [10YR 5/6] striae, few shell fragments, } \\
\text { UB: sharp, bright, carbonate-rich laye }\end{array}$ \\
\hline $12 b$ & $197-215$ & Strong clayey silt, greenish black [Gley2 2.5/10BG], homogenous, UB: gradational \\
\hline $12 a$ & $215-235$ & Strong clayey silt, greenish grey [Gley2 5/10G] with yellowish brown [10YR 5/6] striae, homogenous. UB: gradational \\
\hline 11 & $235-307$ & $\begin{array}{l}\text { Strong clayey silt, greenish grey [Gley2 5/10G], abundant shell fragments [up to several mm], several organic-rich } \\
\text { layers [e.g. 239-244], UB: gradational }\end{array}$ \\
\hline 10 & 307-329 & $\begin{array}{l}\text { Silty clay, dark greenish grey [Gley2 } 3 / 5 B G \text { ], lower boundary is marked by a shell detritus layer [329-326], several } \\
\text { shells [ up to } 3 \mathrm{~cm} \text { ] and shell fragments [mm-cm] especially at the bottom, UB: gradational }\end{array}$ \\
\hline 9 & $329-354$ & Strong silty sand, dark greenish grey [Gley2 3/10BG], homogenous, UB: sharp [shell detritus layer] \\
\hline 8 & $354-383$ & $\begin{array}{l}\text { Strong clayey silt, black [2.5Y 2.5/1], abundant shell fragments [mm-scale] especially at the bottom, few shells [cm] } \\
\text { at the bottom, UB: sharp }\end{array}$ \\
\hline $7 a$ & $383-470$ & $\begin{array}{l}\text { Clayey silt, greenish grey [Gley2 5/10G], few yellowish brown [10YR 5/6] striae/layers, carbonate concretions between } \\
440 \text { and 418, UB: undulating [root channel/bioturbation?] }\end{array}$ \\
\hline $7 \mathrm{~b}$ & $470-515$ & Sandy silt, greenish grey [Gley2 5/10G], homogenous, \\
\hline $7 a$ & $470-534$ & Clayey silt, greenish grey [Gley2 5/10G], few yellowish brown [10YR 5/6] striae/layers \\
\hline 6 & $534-554$ & $\begin{array}{l}\text { Strong clayey silt, yellowish brown [10YR 5/6] striae increasing upward until sediment is entirely yellowish brown, } \\
\text { homogeneous, UB: gradational }\end{array}$ \\
\hline 5 & $554-599$ & $\begin{array}{l}\text { Clayey silt, decreasing clay content to the top, greenish grey [Gley2 5/10G], organic detritus, few shell fragments at } \\
558 \text {, silt-dominated layers at 560-62 and 567, UB: gradational }\end{array}$ \\
\hline 4 & $599-705$ & $\begin{array}{l}\text { Alternating, homogenous sequences }[10-20 \mathrm{~cm}] \text { of sandy silt to silty sand, greenish grey [Gley2 5/10G], UB: sharp/ } \\
\text { undulating }\end{array}$ \\
\hline 3 & $705-863$ & $\begin{array}{l}\text { Weak clayey silt to medium clayey silt, heterogeneous lamination of dark greenish grey [gley2 4/10G] silty and gree- } \\
\text { nish grey [Gley2 5/10G] clay layers of varying thickness [mm-cm], sometimes silt or organic-rich and/or bright, light } \\
\text { greenish grey [Gley2 7/10G] layers intersect fine lamination especially in the upper part, abundant organic fragments, } \\
\text { silt-filled root channels, } 744 \text {-728: sandy silt layer fining upwards, 823-818: sandy silt layer, UB: sharp }\end{array}$ \\
\hline 2 & $863-909$ & $\begin{array}{l}\text { Silty clay, greenish grey [Gley2 } 5 / 10 G] \text {, sometimes intersected by yellowish brown }[10 Y R 5 / 4] \text { and organic-rich layers } \\
\text { up to } 0.5 \mathrm{~cm} \text { thick, UB: gradational }\end{array}$ \\
\hline 1c & 909-920 & Silty clay, abundant shell fragments, dark greenish grey [Gley2 4/10G], UB: sharp \\
\hline $1 \mathrm{~b}$ & $920-930$ & Medium sand, increasing silt content, greenish black [Gley2 2.5/10BG] \\
\hline $1 \mathrm{la}$ & $930-980$ & Medium sand, slightly fining upward, greenish black [Gley2 2.5/10BG], gravel fragments at the bottom \\
\hline
\end{tabular}

\subsection{Laboratory analysis}

When deciphering processes within the lagoon, relative changes and altering trends of elemental concentrations throughout the profile should be interpreted rather than absolute values (KYLANDER et al., 2011). Positive correlations among elements (Fig. 4) confirm the common classification into the following three geochemical groups (cf. chapter 6.1): the marine fraction $(\mathrm{Cl}, \mathrm{Br})$, the carbonate fraction ( $\mathrm{Ca}, \mathrm{Sr}$ ), and the detrital fraction (Al, Si, K, Ti, Rb). Mn and Fe both have an exceptional position and only partially follow the trend of the detrital fraction. S shows no continuous correlation with the other elements. It sometimes tracks the marine indicators or the organic content but is obviously involved in different lagoonal processes (Fig. 5). $\mathrm{Zr}$ is decoupled from the detrital fraction but is vaguely correlated $\left(\mathrm{r}_{\mathrm{Zr}-\mathrm{Cl}}=0.41\right)$ with $\mathrm{Cl}$. It is further associated with the coarse silt/sand fraction (Fig. 5 and 7). As additional proxies, elemental ratios such as
$\mathrm{Mn} / \mathrm{Fe}, \mathrm{Zr} / \mathrm{Rb}$ and $\mathrm{Si} / \mathrm{Sr}$ were analyzed (cf. chapter 6.1).

The chemical composition of the sand-dominated sediment in unit 1 is controlled by the marine indicators $(\mathrm{Cl}, \mathrm{Br})$ and the carbonate fraction $(\mathrm{Sr}, \mathrm{Ca})$. Linked to the latter one, $\mathrm{IC}$ is at its maximum (3.9\%). $\mathrm{Mn} / \mathrm{Fe}, \mathrm{Zr} / \mathrm{Rb}$ and sulfur also display high values while $\mathrm{OC}$ and the $\mathrm{C} / \mathrm{N}$-ratio are at their minimum (Fig. 7).

With the transition to unit $1 \mathrm{~b}$, a gradual increase in terrestrial elements is accompanied by decreasing $\mathrm{Zr} / \mathrm{Rb}$ and an enrichment of silt and clay which culminates in unit 2. Most proxies show a significant change at the transition to unit 2 (8000-7800 cal BP). It is characterized by an abrupt increase of the terrestrial fraction and $\mathrm{Si} / \mathrm{Sr}$ mirroring the declining trend of the IC, the carbonate fraction, the salinity indicators, and $\mathrm{Mn} / \mathrm{Fe}$. In contrast, the $\mathrm{OC}$ rises of up to $2 \%$.

Throughout units 3 and 4, terrestrial elements exhibit a gradual decreasing trend, however, not synchronously. Si is decoupled from the terrestrial fraction. $\mathrm{Zr}$ in fact follows the 

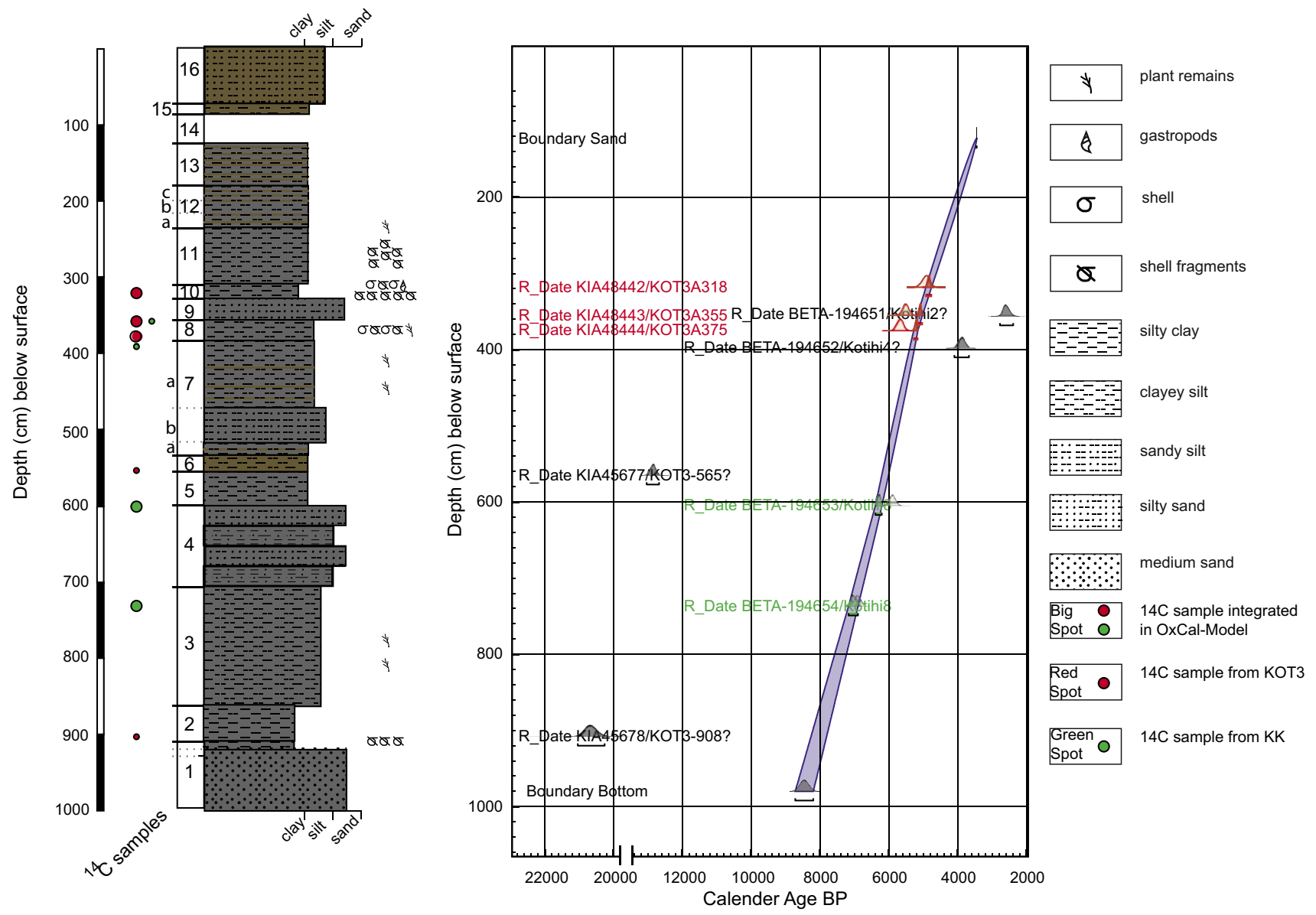

Fig. 3: Lithological units of KOT3 and radiocarbon dates of KOT3 (red) and KK (green) (KONTOPOULOS 3 KoUTSIOS, 2010). Radiocarbon dates used for the establishment of the chronology are marked with big spots. The resulting age-depth-model was calculated with OxCal 4.1.

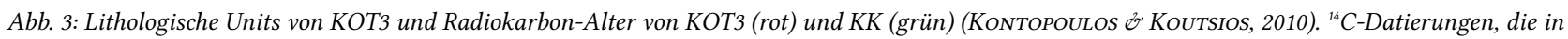
die Chronologie integriert wurden sind mit einem großen Punkt markiert. Das resultierende Alters-Tiefen-Modell wurde mit der Kalibrations Software OxCal 4.1 erstellt.

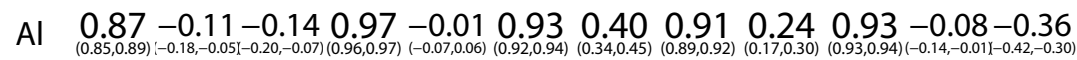

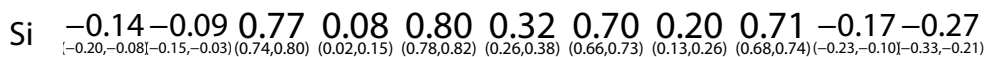

S $\quad-0.16-0.08-0.16-0.08-0.09-0.08-0.03-0.060 .08-0.02-0.02$

Cl $-0.22-0.33-0.12-0.11-0.160 .47-0.13-0.140 .41$

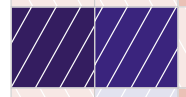

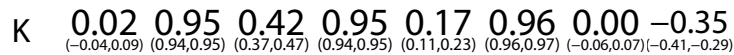

Ca $\underset{(-0.10,0.03)}{-0.04)} 0.37-0.37,-00-0.44-0.170 .50-0.00-0.12$

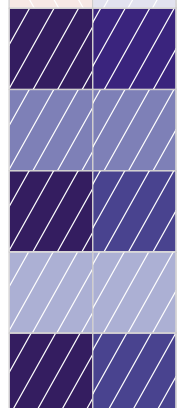

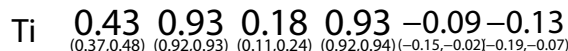

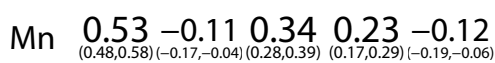

Fe $\quad 0.15 \quad 0.92-0.01-0.29$

$\operatorname{Br} \quad \underset{(0.23,0.35)}{0.0-0.08,0.05)(-0.15-0.0 .02)}$

$\mathrm{Rb} \quad \underset{(-0.12,0.01)(-0.37-0.25)}{-0.06}$

Sr $\quad-0.04$
Fig. 4: Correlogram for KOT3 based on Pearson's correlation coefficients. Blue colors and rising line pattern indicate a positive correlation whereas red colors and falling line pattern indicate negative values. The strength of correlation or anticorrelation increases with color shades. A strong positive correlation between chemical elements suggests a mutual driving mechanism.

Abb. 4: Korrelationsmatrix für KOT3 basierend auf Pearson's Korrelationskoeffizienten. Blaue Kästchen und aufsteigende Linien stehen für eine positive Korrelation und rote Kästchen mit absteigenden Linien zeigen eine negative Assoziation. Der Grad der Korrelation oder Antikorrelation steigt und fällt mit Intensität der Farbe. Ein stark positiver Zusammenhang zwischen chemischen Elementen impliziert, dass die Elementhäufigkeiten vom selben Prozess gesteuert werden. 


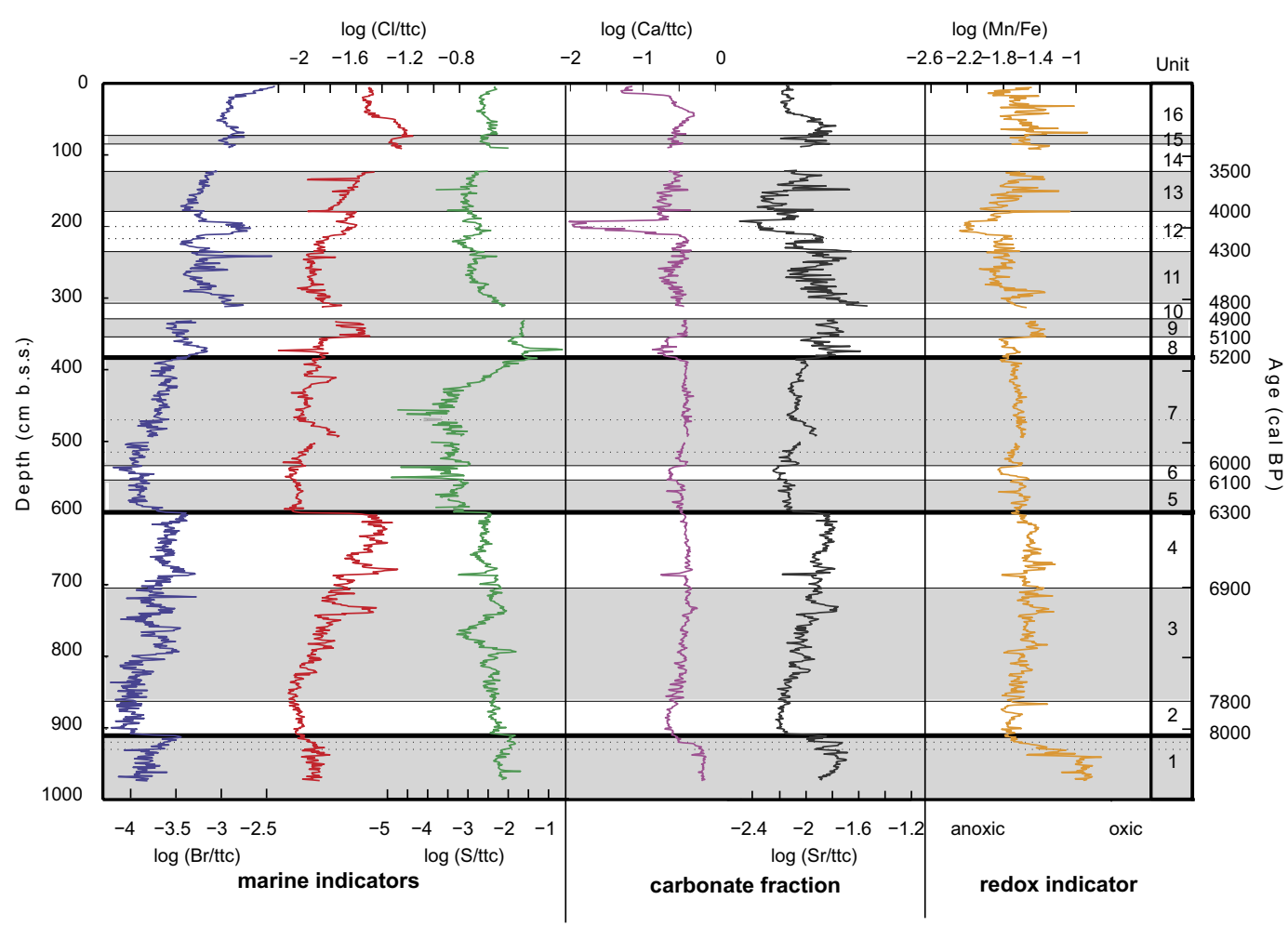

Fig. 5: Geochemical XRF-profiles of the marine fraction, the carbonate fraction, and Mn/Fe (redox-indicator) plotted against depth. Sulphur is often considered a marine indicator but in this case shows a mixed signal. Grouping of elements is based on Pearson's correlation coefficients (Fig. 3). Elemental profiles obtained in cps (counts per second) by XRF are normalized by the total number of counts. The solid black line separates different evolutionary stages.

Abb. 5: Geochemische XRF Profile (in counts per second, cps) von der marinen Fraktion, der Karbonat Fraktion und Mn/Fe (redox Indikatoren). Schwefel zählt generell zu den marinen Indikatoren, zeigt in diesem Fall aber eine Signalüberlagerung, gesteuert von verschiedenen Prozessen. Die Gruppierung der Elemente basiert auf Pearson's Korrelationskoeffizienten. Die geochemischen XRF Profile wurden gegen totale Anzahl der Element-counts normalisiert. Schwarze Linien unterteilen verschiedene Entwicklungsstufen der Lagune.

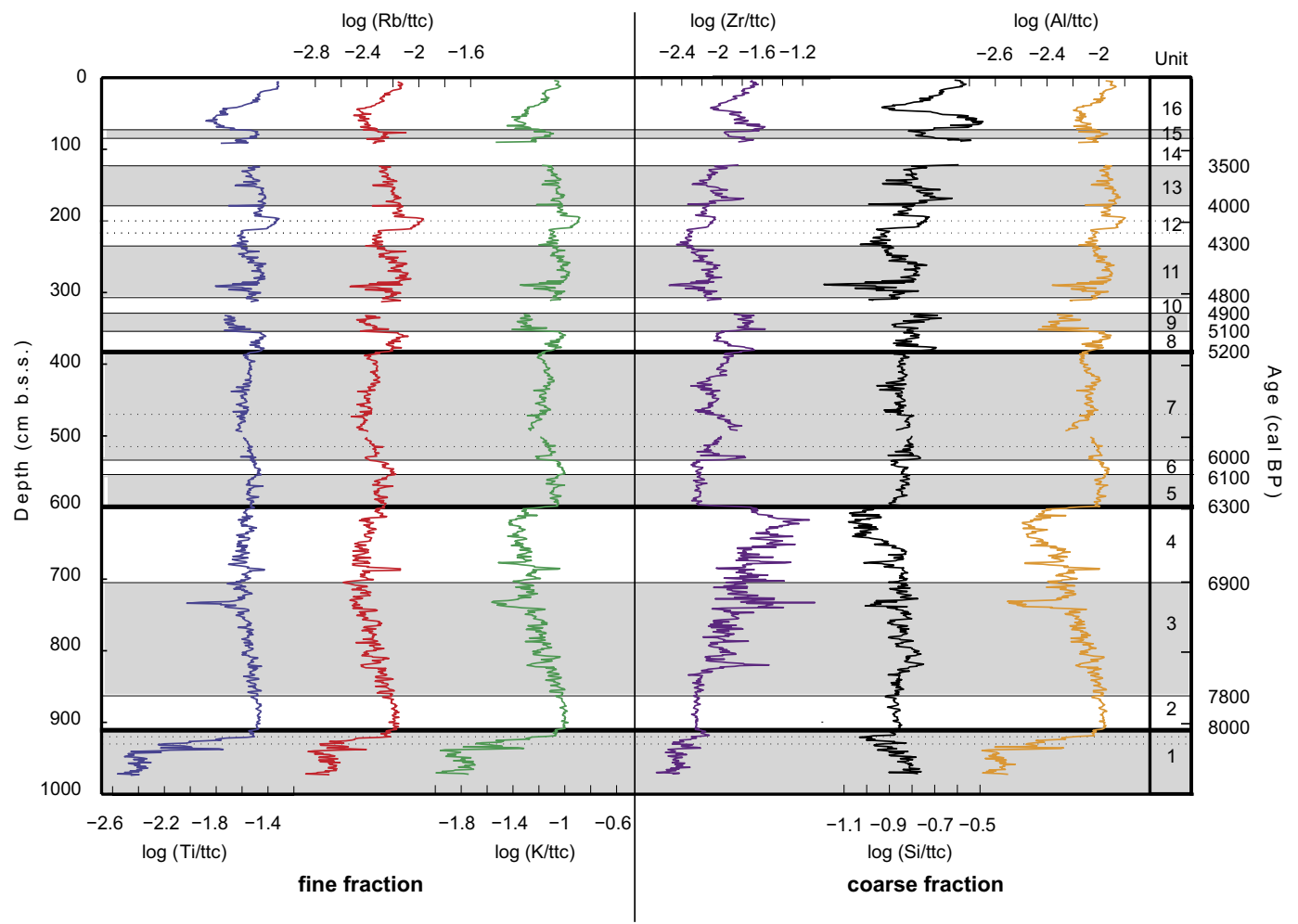

Fig. 6: Geochemical profiles of the terrestrial fraction subdivided into elements predominately associated with fine and coarse-grained minerals. Elemental profiles obtained in cps (counts per second) by XRF are normalized by the total number of counts (ttc). The solid black line separates different evolutionary stages.

Abb. 6: Geochemische XRF Profile (in counts per second, cps) der terrestrischen Fraktion unterteilt nach Elementen, die an grob- und feinkörnige Mineralien gebunden sind. Die geochemischen XRF Profile wurden gegen totale Anzahl der Element-counts normalisiert. Schwarze Linien unterteilen verschiedene Entwicklungsstufen der Lagune. 


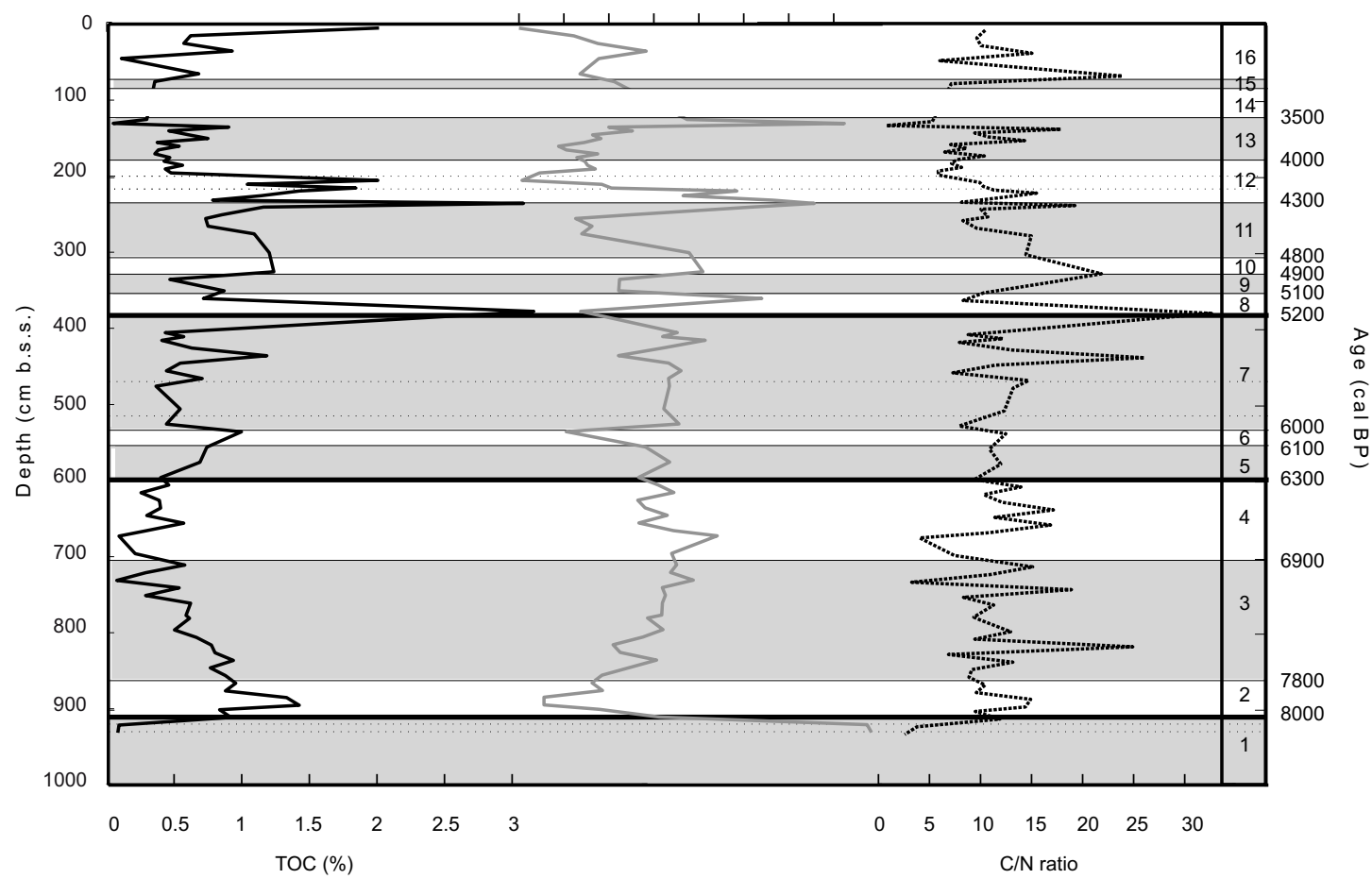

Fig. 7: Inorganic carbon (IC), organic carbon (OC) and CN-ratio of KOT3 plotted against depth. The solid black line separates different evolutionary stages. Abb. 7: Inorganischer Kohlenstoff (IC), organischer Kohlenstoff (OC) das C/N-Verhältnis. Schwarze Linien unterteilen verschiedene Entwicklungsstufen der Lagune.

increase of the marine indicators and the carbonate fraction which is also reflected by an increased contribution of the sand and silt fraction at the expanse of clay. High amplitude fluctuations of the sand and silt fraction reflect rhythmically, alternating sequences of the prevailing homogenous sediment in unit 4. The silt content varies between 21 and $71 \%$ generally mirroring to the trend of the sand fraction. Sporadically, the $\mathrm{C} / \mathrm{N}$-ratio reaches values of 15 (7900 cal BP), 13 (7600 cal BP) and 25 (7500 cal BP) but shows no pronounced trend in the entire profile.

A considerable change reflected by almost every proxy occurs at the transition to unit 5 (6300 cal BP). The geochemical salinity indicators, Sulphur, and the carbonate fraction abruptly decrease whereas terrestrial elements show elevated values, especially $\mathrm{K}, \mathrm{Al}$ and $\mathrm{Si}$. The changing chemical composition is accompanied by a pronounced shift towards the clay and silt fraction reflected by a decreasing $\mathrm{Zr} / \mathrm{Rb}$ ratio. A change in the carbonate sedimentation is indicated by increasing $\mathrm{Si} / \mathrm{Sr}$ and $\mathrm{Ca} / \mathrm{Sr}$ ratios.

Until the end of unit 7 (5200 cal BP) elemental profiles remain relatively stable. The sediment is dominated by silt (up to $90 \%$ ) while the contribution of the sand fraction remains negligible $(<1 \%)$ despite a peak of $13 \%$ around $5700 \mathrm{cal}$ BP which is reflected by the marine proxies.

With the onset of unit $8(5200 \mathrm{cal} \mathrm{BP})$, proxies start to show short-lived fluctuations, well documented by an oscillating $\mathrm{Si} / \mathrm{Sr}$ ratio. The marine proxies are increasing again. However, around $5200 \mathrm{cal} \mathrm{BP}$, parallel to a maximum in S, OC (3.7\%) and C/N-ratio (32), Br increases more significantly than $\mathrm{Cl}$ which is explained by the large affinity of $\mathrm{Br}$ to organic compounds. In unit 9, the elements are in phase again and exhibit high values corresponding to a peak in the sand fraction (13\%) and $\mathrm{Zr} / \mathrm{Rb}$. In contrast, in unit 11 the terres- trial proxies show slightly elevated values and the sediment is enriched in clay. High values of OC (3.6\%), IC (3.2\%) and a high $\mathrm{C} / \mathrm{N}$ - ratio mark the transition to unit 12 where the marine influence is temporally re-established around 4100 cal BP. At the same time, a peak in OC (2.3\%) corresponds to a high $\mathrm{C} / \mathrm{N}$-ratio (10), a low $\mathrm{Mn} / \mathrm{Fe}$ and minimum values of IC $(\sim 0 \%)$ and the carbonate fraction. $\mathrm{Si} / \mathrm{Sr}$ is high, mirroring the decline in $\mathrm{Ca} / \mathrm{Sr}$. Together with a rising $\mathrm{C} / \mathrm{N}$-ratio, the marine proxies, the carbonate fraction and $\mathrm{Mn} / \mathrm{Fe}$ increase gradually in unit 13 . Terrestrial elements especially those enriched in the fine grained fraction are decreasing. The sedimentary record terminates with an erosional unconformity at the upper boundary of unit 13. Parts of unit 14 where lost during coring and the uppermost meter of the core is transformed by anthropogenic activities.

In summary, in coarse sediments (high $\mathrm{Zr} / \mathrm{Rb}$ ) the chemical composition is generally rich in marine proxies and the carbonate fraction while fine grained sediments (low $\mathrm{Zr} / \mathrm{Rb}$ ) show a high concentration of terrestrial proxies.

\section{Discussion}

\subsection{Shoreline evolution}

Inferred from simultaneous changes in proxy data, the sedimentary sequence can be subdivided into four evolutionary stages: Stage 1 ( $8500-8000 \mathrm{cal}$ BP) is characterized by coarse, marine influenced elements. Stage $2(8000-6300 \mathrm{cal}$ BP) comprises an enhanced concentration of fine grained sediments enriched in terrestrial elements which are progressively replaced by coarse marine influenced sediments. Stage 3 (6300-5200 cal BP) is controlled by silt-dominated, terrestrial sediments with only sporadic traces of marine proxies. Stage 4 (5200 cal BP-present), in contrast shows oscillating 


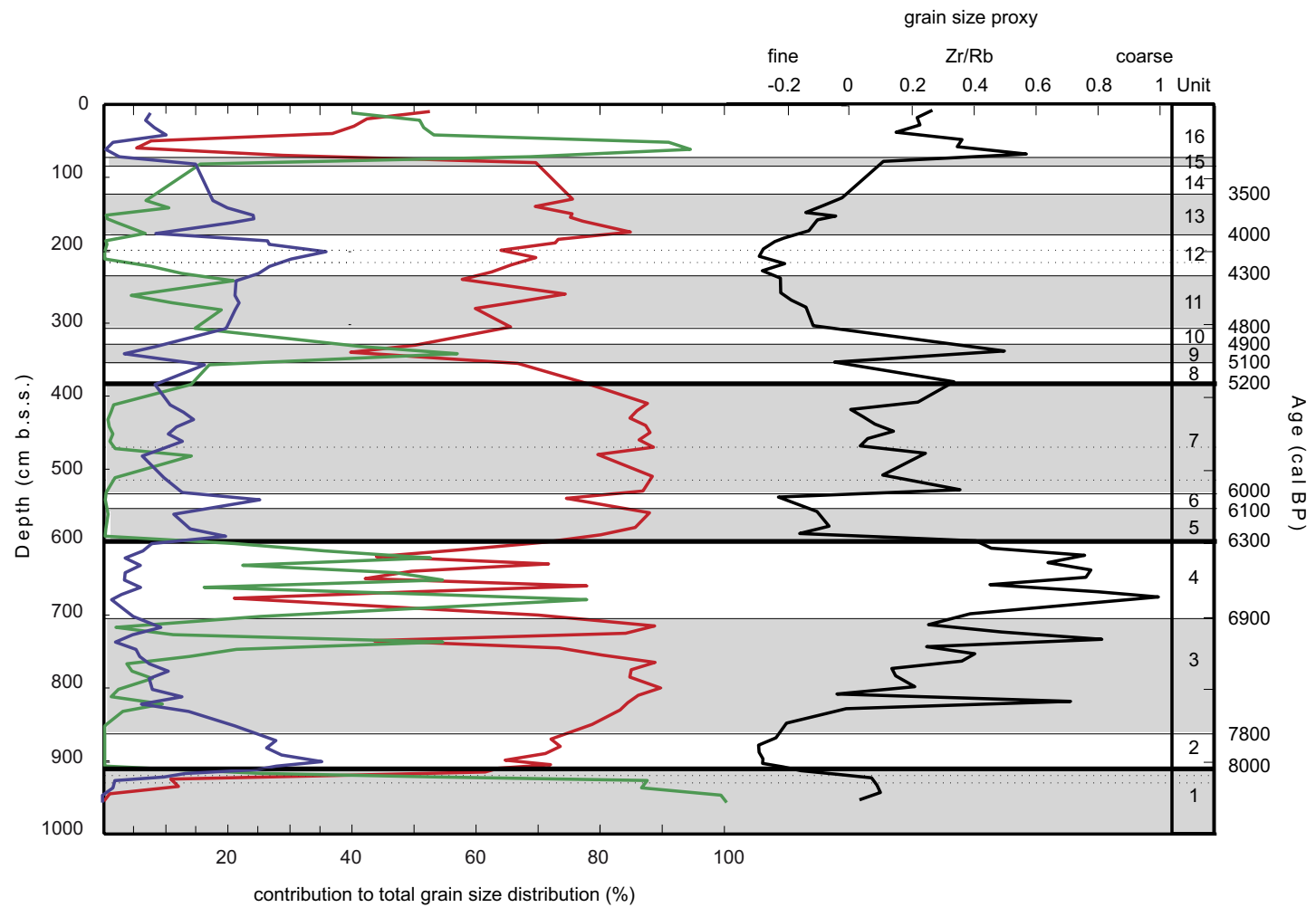

Fig. 8: Percental contribution of clay (blue), silt (red) and sand (green) to the total grain size distribution in comparison with log (Zr/Rb) (grain size proxy). The solid black line separates different evolutionary stages.

Abb. 8: Prozentualer Anteil von Ton (blau), Schluff (rot) und Sand (grün) an der gesamten Korngrößenverteilung in Vergleich zu log (Zr/Rb) (Korngrößenproxy). Schwarze Linien unterteilen verschiedene Entwicklungsstufen der Lagune.

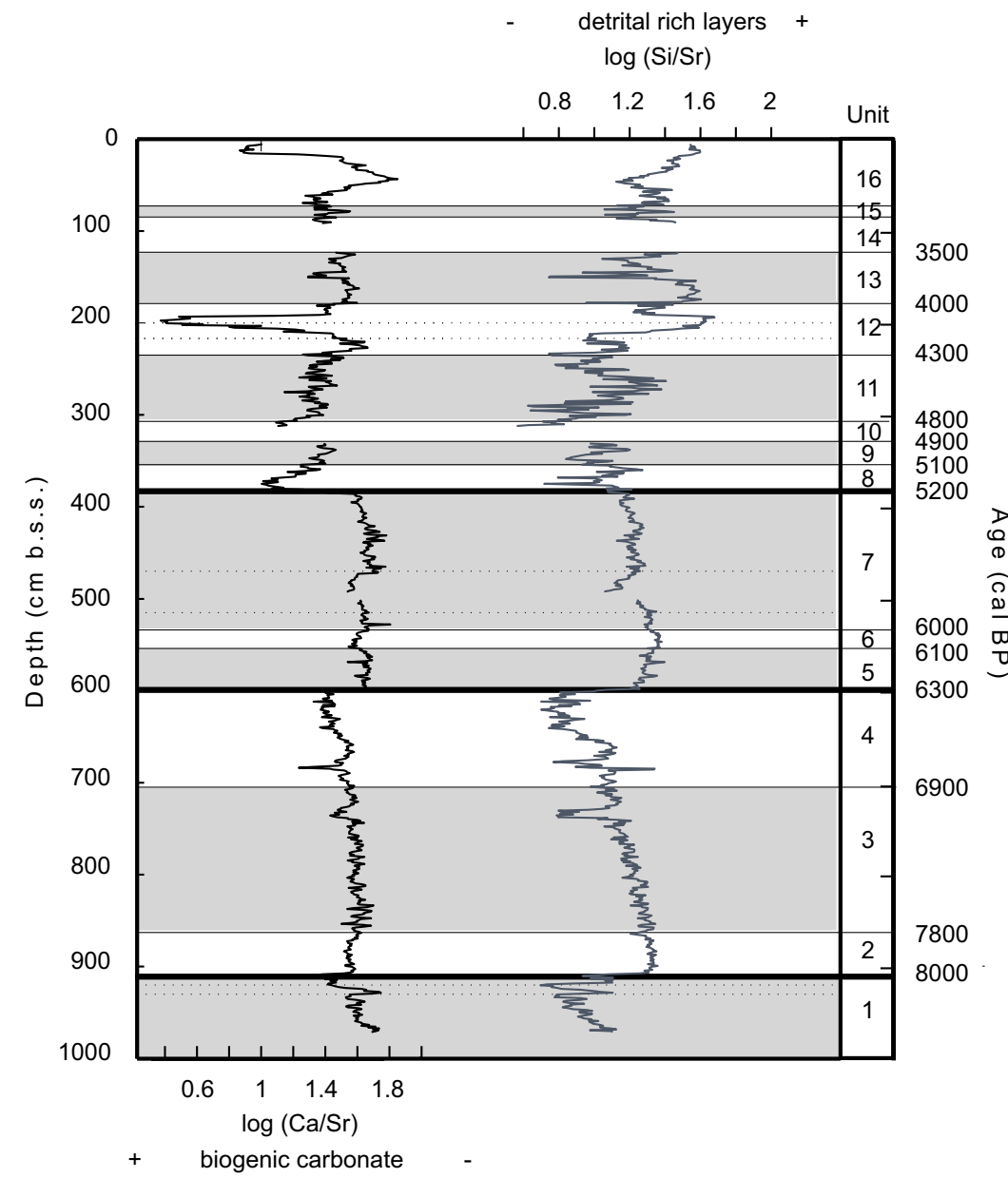

Fig. 9: $\mathrm{Si} / \mathrm{Sr}$ and $\mathrm{Ca} / \mathrm{Sr}$.

Abb. 9: $\mathrm{Si} / \mathrm{Sr}$ und $\mathrm{Ca} / \mathrm{Sr}$ 
profiles with successive phases of both, terrestrial and marine dominance. These four evolutionary stages document the palaeoenvironmental evolution of the Kotychi Lagoon.

Stage 1 , comprising only unit 1 , represents the marine phase of the sedimentary succession which is characterized by coarse carbonate-rich sediments high in $\mathrm{Cl}$ and $\mathrm{Br}$ deposited in a well oxygenated environment (high $\mathrm{Mn} / \mathrm{Fe}$ ratio) with low bio productivity (almost lowest OC in the profile). Based on the low $\mathrm{C} / \mathrm{N}$-ratio the contribution of terrestrial organic matter rich in cellulose and lignin is negligible.

Based on this data, it is assumed that the palaeoshoreline was located several $\mathrm{km}$ east of its present position, which confirms the assumptions of KRAFT et al. (2005). The slowly increasing silt content and the simultaneously increasing signal of the detrital fraction gradually starting around 8200 cal BP (Unit 1b) indicate the gradual development of a back barrier environment where fluvial sediments from the hinterland start to accumulate. Abundant shell fragments indicate the transition to ecologically favorable conditions.

With the onset of stage 2, comprising units 2, 3, and 4, lagoonal conditions have developed. A tenfold increase of the sedimentation rate supports the hypothesis of a sediment trap in the back barrier environment. Clayey sediments (low $\mathrm{Zr} / \mathrm{Rb}$ ) enriched in terrestrial elements point to a quiescent deposition environment were sediments derived from the hinterland accumulate. Peaks in $\mathrm{C} / \mathrm{N}$-ratio indicated a binary mixture of terrestrial and aquatic organic matter which confirms the terrestrial sediment source. It is assumed that in the stagnating water vertical mixing was restricted and in the oxygen depleted environment (low $\mathrm{Mn} / \mathrm{Fe}$ ) productivity was still extremely low (low OC). The greyish color of the sediments confirms that no oxygen was available for the oxidization of $\mathrm{Fe}^{2+}$. The drop of the IC content reflects the absence of marine $\mathrm{Ca}$-rich sand and a rising $\mathrm{Si} / \mathrm{Sr}$ points to enhanced detrital silicate deposition. This indicates the transition to a restricted marine influence.

The continuing sediment supply from the hinterland throughout stage 2 lead to further accumulation of fine grained terrestrial sediments (high amount of detrital fraction and low $\mathrm{Zr} / \mathrm{Rb}$ ) in the back barrier environment, and promoted the growth of the barrier island. Hence, the lagoon was perfectly sheltered favoring the development and preservation of finely laminated sediments (Unit 3), characteristic for a quiescent, oxygen-poor environment with limited bioproductivity (low $\mathrm{Mn} / \mathrm{Fe}$ and low $\mathrm{OC}$ ) and no bioturbation of higher organisms which would destroy the lamination.

A decoupling of $\mathrm{Al}$ and $\mathrm{Si}$ between 822 and $660 \mathrm{~cm}(7500$ and $6600 \mathrm{cal}$ BP) suggests an increased deposition of biogenic silicate possibly associated with diatom productivity. However, this hypothesis needs further verification. Additionally, rising IC indicate carbonate precipitation in the lagoonal environment most likely associated with light colored layers in the laminated sediments (higher IC). They probably reflect an annual cycle. During spring/summer, enhanced biological activity of microorganism such as diatoms results in $\mathrm{CO}_{2}$ consumption leading to autochthonous, biochemical precipitation of whitish calcite layers. In winter, surface run off and creeks draining the lagoon provide clastic sediments from the catchment and build up a layer composed of mineral grains, reworked carbonate, shell fragments and organic detritus (BRAUER, 2004). However, the poor state of preservation of the laminae hampers detailed interpretations.

In unit 3, layers of sand for example at $731 \mathrm{~cm}(7000 \mathrm{cal}$ $\mathrm{BP}$ ) correlating with peaks in $\mathrm{Cl}$ and $\mathrm{Br}$, with rising IC, and higher $\mathrm{Zr} / \mathrm{Rb}$ imply marine intrusion into the lagoonal environment.

Marine intrusion into coastal water bodies is often ascribed to high-energy transport associated with extreme wave events such as tsunamis or storms. Several authors believe to have found evidence for the occurrence of tsunamis in coastal environments all around the world (GoFf et al., 2012). It is even hypothesized that the ancient city of Olympia approximately $50 \mathrm{~km}$ southeast of Kotychi was destroyed by a tsunami (Vöтt et al., 2011).

However, due to the homogenous nature of the marine sediments in KOT3 deposition associated with high-energy transport is neglected. Sediment structures like muddy intraclasts, were not detected as well as fining upward sequences including abundant faunal remains of marine origin which are often associated with extreme wave events like tsunamis or severe storms (MORTON et al., 2007; GoFf et al., 2012).

By 6900 cal BP (unit 4) the barrier, which entrapped the lagoon, was at least partially flooded as indicated by high $\mathrm{Cl}$ and $\mathrm{Br}$ and a reduction of the terrestrial fraction. Homogenous, marine sandy silt was deposited and saltwater intrusion initiated bottom ventilation as suggested by a slightly increasing trend of $\mathrm{Mn} / \mathrm{Fe}$.

Based on this evidence, stage 2 is assumed to represent a first, short-lived episode of shoreline progradation and barrier island accretion, which isolated the shallow lagoon but successively the coastline retreated. So far, the existence of a sequence of lagoons fringing the Elean coast for at least 7000 years has only been postulated (RAPHAEL, 1973, 1978; KRAFT, 2005; Kontopoulos \& Koutsios, 2010). With an age of 8000 cal BP, the sedimentary evidence from KOT3 for the first time presents chronological control for the onset of barrier accretion and lagoon development.

A distinct change in sedimentation occurred around 6300 cal BP and marks the beginning of stage 3 encompassing units 5,6 , and 7 . The marine influence $(\mathrm{Cl}, \mathrm{Br}$ and $\mathrm{S})$ abruptly ceases and an increase in terrestrial sediments dominated by clayey silt (low $\mathrm{Zr} / \mathrm{Rb}$ ) implies that riverine outflow to the sea is blocked again and a sediment trap developed behind a barrier. The shift towards a terrestrial sediment accumulation is again well documented by the elevated $\mathrm{Si} / \mathrm{Sr}$ pointing to a detrital dominated sedimentation at the expense of carbonates.

Around $6000 \mathrm{cal} \mathrm{BP}$, shell fragments and altering layers of grey and brown shades rich in clay (Tab. 2) indicate an alternation of waterlogged phases and drier conditions allowing the oxidization of ferric compounds. A high concentration of terrestrial elements $(\mathrm{Rb}, \mathrm{Ti}, \mathrm{K})$ linked to the fine fraction opposed to low values of $\mathrm{Cl}$ and $\mathrm{Br}$ is enriched in unit 6 implying terrestrial condition at this time. The decline of $\mathrm{Mn} /$ Fe seems to reflect a lowering of the $\mathrm{pH}$ due to oxygenation of the sediments, a process often contributing to soil acidification. A minimum of IC caused by carbonate dissolution in the acid environment supports this hypothesis.

Isolated brown, mm-scale layers in unit 7 result from episodic drought but are rapidly succeeded by lagoonal deposits indicating a low water table susceptible to a changing 
hydrological regime. The precipitation of carbonate concretions between 440 and $418 \mathrm{~cm}$ (verified by a strong response to $\mathrm{HCl}$ ) confirms an increased trend towards aridity around 5500-5400 cal BP.

As stage 3 is interpreted to represent the terrestrial/marginal part of the lagoon, the lagoon itself and hence the shoreline must have been located further west or the lagoon has been silted up by progradation of the fluvial influences facies. However, the presence of marine layers associated with homogenous, coarse sediments high in $\mathrm{Cl}, \mathrm{Br}$ and $\mathrm{S}$ deposited in an oxygenated (rising $\mathrm{Mn} / \mathrm{Fe}$ ) environment $7 \mathrm{~b}(515-470 \mathrm{~cm}$; 5800-5700 cal BP) suggest short-lived marine intrusion and the return to marine influenced conditions in the lagoon.

Stage 4 including units 8 to 16 is characterized by pronounced, short-lived fluctuation of many proxies. A sharp undulating contact between unit 7 and $8(383 \mathrm{~cm}$; $5200 \mathrm{cal}$ BP) marks the transition to stage 4. Abundant shell fragments and shells like Cerastoderma sp. and Spisula sp., some of them in growth position, indicate the return of lagoonal conditions which is also confirmed by the marine proxies $\mathrm{Br}$ and $\mathrm{Cl}$. The decoupling of $\mathrm{Cl}$ and $\mathrm{Br}$ coincides with a maximum in $\mathrm{OC}$ indicating that the opposing trend may be explained by a large affinity of $\mathrm{Br}$ to organic compounds. Likewise, the correlation of S and OC implies that $\mathrm{S}$ in this unit is also bound to organic complexes. Terrestrial elements linked to the fine-grained fraction are dominating in the strong clayey silt (low $\mathrm{Zr} / \mathrm{Rb}$ ) derived from the hinterland.

The opposing trends of $\mathrm{Ca}$ and $\mathrm{Sr}$ are attributed to a changing composition of the carbonate source. The decline in Ca seems to be connected to the dissolution of IC which might be attributed to the partial decomposition of enriched OC. A subsequent release of $\mathrm{CO}_{2}$ lowers the $\mathrm{pH}$ to favor carbonate dissolution (DEAN, 1999). However, the carbonate available in the sediment seems to be dominated by Sr-rich, biogenic carbonate as inferred from low $\mathrm{Ca} / \mathrm{Sr}$. Keeping in mind high OC values, the undulating sharp lower contact to unit 7 may either be interpreted as a consequence of bioturbation or represents a sediment-filled root channel.

With another sharp transition towards unit 9 around $4900 \mathrm{cal}$ BP, the lagoonal sediments are replaced by homogeneous, strong silty sand showing the typical marine signature characterized by coarse sediments high in $\mathrm{Cl}$ and $\mathrm{Br}$ and the $\mathrm{Ca}$ fraction. The apparent decrease of $\mathrm{Br}$ compared to unit 8 can be ascribed to a decline of the $\mathrm{OC}$ no longer fixing Br. The sharp contact indicates an event of erosion. However, the homogenous sediments represent an episode of sea level rise rather than an extreme wave event. In contrast, a layer of fragmented shells uncomformably overlaying the marine deposits could be attributed to an extreme wave event around $4900 \mathrm{cal} \mathrm{BP}$. The sharp, erosional contact indicates high-energy transport and the distinct degree of fragmentation of shells results from deposition under turbulent conditions. Following the marine influenced deposition, there was a return to quiescent, lagoonal conditions characterized by the abundance of shells; Cerastoderma sp. reaches up to $3 \mathrm{~cm}$.

The gradual decrease of shells in growth position, OC, and the geochemical proxies indication marine influence imply the termination of the fully lagoonal conditions between 4100 and 4300 cal BP (unit 11). A slight coarsening of the sediments towards clayey silt may be the result of seaward progradation of the profundal zone of the lagoon. However, the grey color typical for reduced mineral compounds due to an oxygen-depleted environment indicates still waterlogged conditions. Numerous shell fragments indicate ecologically favorable condition and the presence of wave action required for their fragmentation and deposition. The high OC towards the end of unit 11 results from a combined contribution of aquatic and terrestrial matter (C/N-ratio: 19) and supports the hypothesis of ecologically favorable condition.

The appearance of brown shades in unit 12 indicates a lowering of the water level, which allowed bottom ventilation and subsequent oxidization of ferric compounds giving the sediment its characteristic color. The environment progressively changed from a fully lagoonal to a lagoonal/ marginal environment. However, this trend is interrupted by a short-lived episode of lagoonal predominance around 4100-4000 cal BP. High values of $\mathrm{Cl}, \mathrm{Br}$, and S associated with the black color of the sediments suggest the return of water-saturated, anoxic conditions (lowest $\mathrm{Mn} / \mathrm{Fe}$ ). The abrupt decrease of both, Sr and Ca seems to be related to IC dissolution (low IC).

Towards the end of unit 12, around $4000 \mathrm{cal}$ BP the water level has dropped and oxygenated conditions (slightly rising $\mathrm{Mn} / \mathrm{Fe}$ ) returned. The marine influence is declining and a light colored horizon at $179 \mathrm{~cm}$ (3900 cal BP) strongly responding to diluted $\mathrm{HCl}$ indicates carbonate precipitation possibly as a result of dry conditions.

Around $3900 \mathrm{cal} \mathrm{BP}$, the lagoonal/marginal part has further prograded seaward and the sedimentary evidence of unit 13 (3500-3900 cal BP) documents the coexistence of stream channel and adjacent flooded areas characteristic for a floodplain. During periods of high discharge, coarse sediments are deposited in episodically activated stream channels (silt layers unit 13), which are partly cutting the floodplain. The brownish color of the sediments implies the presence of oxygen supported by rising $\mathrm{Mn} / \mathrm{Fe}$. Elevated $\mathrm{Cl}$ and $\mathrm{Br}$ values suggest periodic flooding but charcoal accumulation at the top of the unit clearly points to a terrestrial provenance of the sediments.

The coarse material of unit $14(85-123 \mathrm{~cm})$ uncomformably overlaying unit 13 could not be recovered. Judging from a small sample that could be retained in the field, the grain size, the fragmented, redeposited shells $(>2 \mathrm{~mm})$ and the incorporated, sharp edged gravel seem to reflect high energy deposits probably associated with a river channel crossing the floodplain and discharging into the lagoon. A temporal onset for the river activity cannot be given based on the agedepth-model as it has to be assumed that the river deeply cut in to the floodplain introducing a non quantifiable erosional gap and hence uncertainty into the age-depth-model. Accordingly, the interpretation of the sedimentary succession terminates with the lower, erosive boundary of the sand layer around $3500 \mathrm{cal} \mathrm{BP}$. The sediments overlying this fluvial deposit are subject to soil formation and intensive agriculture and can therefore not be interpreted in a palaeoenvironmental context.

Based on proxy evidence, it can be assumed that stage four is characterized by a rapid succession of lagoonal and terrestrial deposition milieus, which points to unstable environmental conditions. 


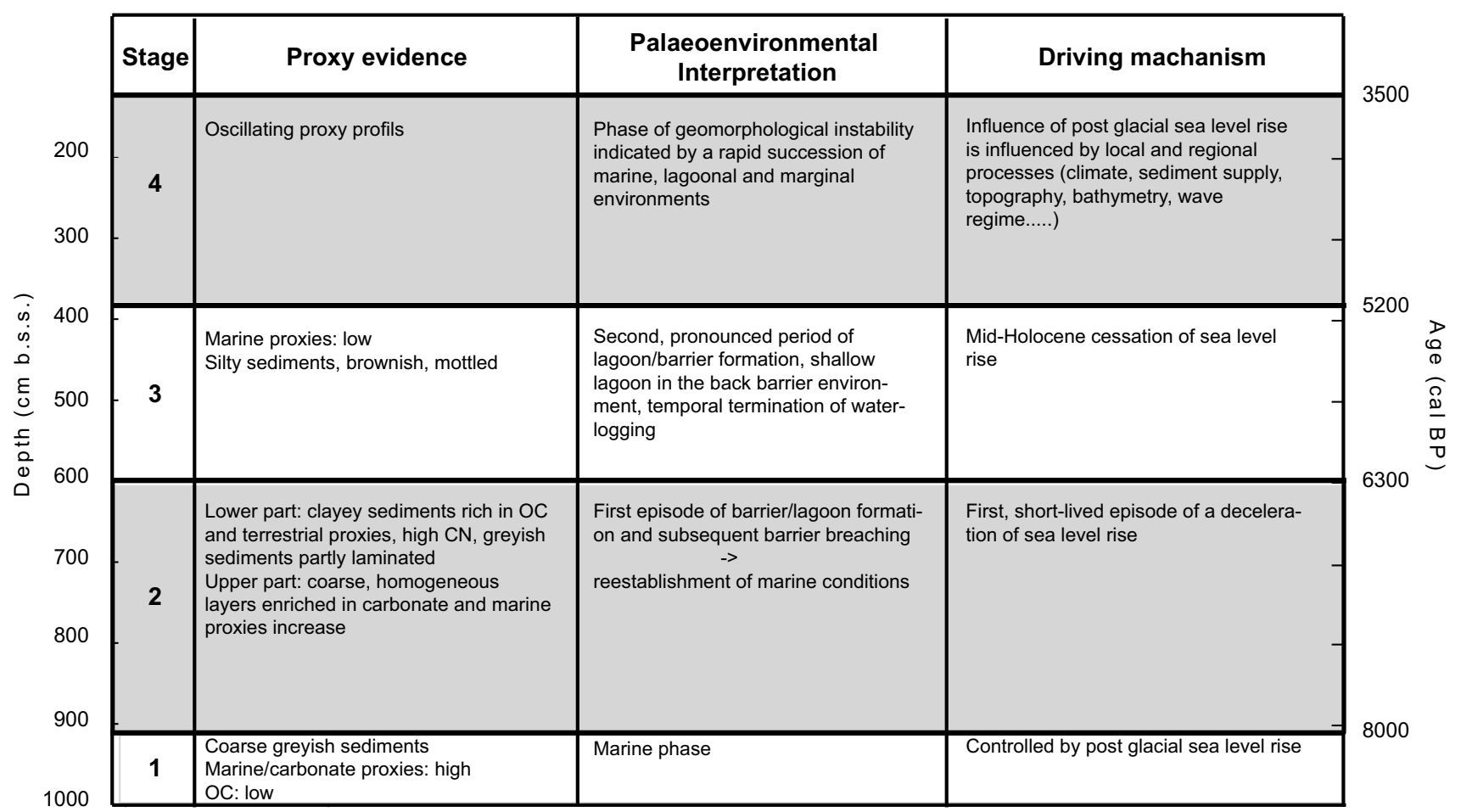

Fig. 10: Summary of proxy evidence and palaeoenvironmental interpretation.

Abb. 10: Zusammenfassung der Proxies und ihre umweltgeschichtliche Interpretation.

\subsection{Regional Synthesis}

The data presented in this study provide evidence for the existence and yet the temporal onset for the development of a Holocene coastal logoon as proposed by KRAFT et al. (2005), RAPHAEl $(1973,1978)$ and Kontopoulos \& Koutsios (2010). However, RAPHAEL $(1973,1978)$ assumed an early phase of coastal progradation during Hellenistic Times, and KonToPOULOS \& Koutsios (2010) suggested an age of 4000 BP, results from this study provide evidence for a period of pronounced, coastal progradation starting 6300 cal BP (stage 3) and an early but only short-lived phase around 8000 cal BP (stage 2). The latter is approximately in accordance with the oldest proposed barrier accretion cycles proposed by KRAFT et al. (2005) during Late Mesolithic to Neolithic Times.

Further, KRAFT et al. (2005) present evidence for major sediment surges in the Early Helladic (3000-2000 cal BC), in Early Mycenaean times (1700-1400 cal BC), and from Classical (500-323 cal BC) to modern times.

The pronounced period of coastal progradation starting $6300 \mathrm{cal}$ BP (stage 3) is not in accordance with the evidence presented by KRAFT et al. (2005). However, enhanced sediment supply in the Early Helladic and Early Mycenaean Times can also be inferred from the sedimentary record of the Kotychi Lagoon (unit 11 and unit 13). A certain time lag can be attributed to a site-specific evolution or is a result of restricted dating accuracy, which cannot be neglected in coastal environments where ${ }^{14} \mathrm{C}$ dating is limited by a hardly quantifiable marine reservoir correction.

Evidence for three major sediment surges during Hellenistic (323-30 cal BC), Roman (30 cal BC - $330 \mathrm{cal} \mathrm{AD)} \mathrm{and}$ early Medieval times ( $330 \mathrm{cal} \mathrm{AD} \mathrm{-} 1453 \mathrm{cal} \mathrm{AD}$ ) proposed by RAPHAEL $(1973,1978)$ could not be supported by this study because the sedimentary record of the past 3500 years is not preserved in KOT3. The river channel producing the erosional gap further hampers a comparison to the palaeoenvironmental interpretation of KonTOPOULOS \& Koutsios (2010) derived from the same lagoon. Kontopoulos \& Koutsios (2010) distinguished three evolutionary stages from lagoonal (earlier than 7000-3810 cal BP) towards a terrestrial period (3810-1400 cal BP) followed by a transgressive phase (1400 cal BP-present). Whereas the basal part of the cores show a similar evolution, the mid-Holocene phase of coastal progradation corresponding to stage 3 in KOT3 is not identified by Kontopoulos and Koutsios (2010). In contrast, in KK lagoonal bottom facies interrupted by an episode of stream channel influence in a depth of $440-470 \mathrm{~cm}$ are prevailing (Kontopoulos $\&$ Koutsios, 2010). This probably introduced the erosional gap in KK much earlier than in KOT3 and is held responsible for the evolutionary discrepancy of the cores in the upper part.

\subsection{Driving forces of coastal pro- and retrogradation}

On a local scale, coastal morphology is highly susceptible to terrestrial sediment supply. Terrestrial environments play a profound role controlling sediment dynamics as material is eroded from the hinterland, transported by rivers, and entrained in littoral currents to shape the coast by creating barriers, lagoons, marshes or deltas. However, the sea level acts as a baseline to which a broad spectrum of processes adjusts. Hence, it controls the long profile of rivers, which influences sedimentation and erosion in the lowlands. Consequential, in the transitional zone were rivers and the sea merge barrier migration is the morphological response to the relation of sediment supply rates and the rate of sea level rise. A disequilibrium results in an adjustment of process and form (Costas et al., 2009; Plater \& Kirby, 2011). 
As causes for the perturbation of this disequilibrium and the balancing processes initiating shoreline migration, either changing sea level rates associated with the decay of the continental ice sheets and changes the ocean volume or varying sediment fluxes can be considered (LAMBECK \& Purcell, 2005; Costas et al., 2009). The latter one can be a composite of both, naturally induced soil erosion or anthropogenically enforced hinterland exploitation and soil degradation that translates into sedimentation in the lowlands (RAPHAEl 1973, 1978; KrAft et al., 2005; Dinis et al., 2006).

Of course, local tectonic processes can influence the interplay of seal level rise and sediment supply. It controls the nature of the coastal environment either by gradual uplift or subsidence or by a sudden, impulsive vertical displacement. In this context, tectonic activity in the coastal area itself as well as in the hinterland has to be considered because it controls relief energy and hence sediment delivery. However, the quantification of tectonic control over geological timescales is difficult (Plater \& Kirby, 2011).

Further, short-term processes as extreme wave events can create an episodic disturbance. Costas \& AlEJo (2007) for example report sporadic barrier breaching associated with increased wave energy striking the barrier during periods of increased storminess. After the initial disturbance, the coastal system needs a certain time to readjust and adapt to the boundary conditions.

With regard to the diverse driving factors of coastal evolution in the Kotychi area, stage 1 is influenced by the aftermath of the melt down of the continental ice sheets, which initiated ocean volume expansion and subsequently rapid sea level rise. Until 8000 cal BP the shoreline was located several $\mathrm{km}$ landward of its present position.

With vanishing of the ice sheets ocean volume remained constant attenuating the rate of sea level rise and allowing local signals to overcompensate the eustatic signal (FrEITAs et al., 2003; BAO et al., 2007; Costas et al., 2009). In the Mediterranean, widespread evidence for a weakening of the eustatic signal and the development of lagoon barrier systems clusters around 5500-6500 BP (DiNIs et al., 2006; BAO et al., 2007; CostAs et al., 2009). However, stage two starting around $8000 \mathrm{cal} \mathrm{BP}$ seems to represents an early phase the mid-Holocene cessation of sea level rise which gives local factors such as sediment availability an accentuated the role.

This early stage sea level deceleration reflects the hypothesis of STANLEY \& WARNE (1994), who postulate worldwide delta progradation as a result of fluvial sediment input overcompensating the declining rate of sea level rise between 8500 and 6500 BP. On a regional scale the hypothesis of a stabilization of the sea level shows analogies to the results KRAFT et al. (2005) and it approximately confirms the results of Avramidis et al. (2012) who described sand barrier evolution and brackish/lagoonal back barrier conditions around $8540 \mathrm{cal}$ BP in the Alykes Lagoon on Zakynthos Island 30-40 $\mathrm{km}$ west of Kotichy Lagoon.

Human induced soil erosion creating a surplus of sediments must also be considered. An array of studies evaluated and summarized by DusAr et al. (2011) proposes a causal relationship between anthropogenic landscapes modification and enhanced sediment dynamics in the Mediterranean. It is common assumption that deforestation in the Mediterranean dates back to the Neolithic (KRAFT et al., 2005). Indeed, there is evidence for Early Neolithic human activity in the study area (RAPHAEL, 1973; Williams, 2004). However, their ecological footprint is considered to have been small as indicated by pollen data (LAzArova, Koutsios, \& KontoPOULOS, 2012) and so far no anthropogenically induced sediment surges have been reported in the region during Neolitic Times (RApHAEL, 1973, 1978; Kraft et al., 2005; KontopouLos \& Koutsios, 2010). Hence, human induced soil erosion can be neglected as a source for the perturbation of the balance between sea level rise and sediment supply around $8000 \mathrm{cal}$ BP. In fact, hinterland erosion and sedimentation in the Kotychi area appears to have been on a moderate level inferred from the finely laminated sediments representing a quiescent, low-energy sedimentation regime and further from an immature, semipermeable sand barrier which was flooded by a slower but after all rising sea level around 6600 cal BP.

Accordingly, temporal analogies of circum-Mediterranean lagoon formation indicate that an early stage of sea level deceleration led to a surplus of sediments in the transitional area where the Peneus River and the Ionian Sea merge which, initiated barrier formation in the prograding delta. Hence, an attenuation of the eustatic signal was the driving force of coastal progradation around $8000 \mathrm{cal} \mathrm{BP}$. The gradual, subsequent flooding of the barrier environment is ascribed to a slower but after all rising sea level. However, an episode of subsidence, lowering the overflow threshold of the barrier could also be possible but is hard to prove.

A shift toward terrestrial marginal conditions either associated with a seaward migration of the lagoon or silting up of the back barrier environment characterize stage 3 and indicate an additional imbalance between sea level rise and sediment supply. The beginning of this stage coincides with circum Mediterranean lagoon formation and the traditionally mentioned cessation of the post-glacial sea level rise around 6500 and 5500 BP (LAMBeck \& PURCELl, 2005; Dinis et al., 2006). For this period, FouACHE et al. (2008) report a complex of coastal barriers encompassing the Thessaloniki plain, on the Iberian Peninsula Costas et al. (2009), BAo et al. (2007) and Freitas et al. (2003) just to name a few, postulate lagoon and wetland formation. At the coastal plain of Marathon, Greece, PAvlopoulos et al. (2006) ascribe a sequence of lagoonal deposits to the stabilization of sea level rise just as Kontopoulos \& Avramidis (2003) at the Aliki Lagoon, north Peloponnese.

However, the deceleration of sea level rise and a subsequent surplus of sediments must not be the sole reason for the cessation of the waterlogged conditions during stage 3 . In the mid-Holocene, a trend towards a general aridification is inferred from $\delta^{18} \mathrm{O}$ and $\delta^{13} \mathrm{C}$ records of speleothems in Israel (BAR-MATTHEWs et al., 2003), or by geochemistry and pollen data from crater-lake sediments in central Turkey (Roberts et al., 2001). However, the transition towards aridity shows spatial variability throughout the Mediterranean (cf. LESPEZ, 2003; JALuT et al., 2009; DusAR et al., 2011; FinNÉ et al., 2011). In a comprehensive synopsis of Holocene climate in the eastern Mediterranean, FINNÉ et al. (2011) propose a transition towards increased aridity gradually starting 5400 BP, which could have triggered climatically induced water table oscillation. The appearance of carbonate concretions in the Kotychi record around 5500-5400 cal BP supports the hypothesis and implies dry conditions in the Kotychi area during this time. 
Anthropogenic induced soil erosion in stage 3, coinciding with the Late Neolithic is still considered to be on a moderate level and hence, appears to be a minor factor initiating enhanced sediment supply.

Consequently, prevalent temporal analogies of lagoon formation justify the hypothesis that at the beginning of stage 3 a widespread attenuation of the eustatic signal resulted in delta progradation of the Palaeo-Peneus River delta. Entrained in littoral currents the surplus sediments was redistributed and reorganized to form a lagoonal back barrier environment. The cessation of the waterlogged conditions might have been a composite of an attenuated sea level rise amplified by climate forcing which with diminishing dominance of the eustatic signal is able to exert influence on coastal morphology.

Stage 4 is characterized by a comparable rapid succession of varying deposition environments indicating reoccurring fluctuation in the sediment budget. After the pronounced period of coastal progradation (stage 3), lagoonal conditions are returning again indicating an episode of barrier breakdown around $5200 \mathrm{cal} \mathrm{BP}$. It seems that hinterland sediment supply was restricted. With a still moderate level of human activity in the Elean uplands and climate conditions obviously not favoring enhanced sediment fluxes, a slower but nevertheless rising Ionian Sea flooded the lagoon. Apparently starved of continuous sediment supply, the barrier became progressively impermeable allowing marine intrusion (unit 9) and it was of course not mature enough to withstand extreme wave events (shell fragments unit 10).

Starting $4700 \mathrm{BP}$, lagoonal/marginal conditions are prevailing passing into progressive terrestrial conditions around $4300 \mathrm{BP}$ indicating that the profundal zone must have migrated seaward or has been silted up. At least a slight increase in sediment supply must have occurred which could be attributed to gradually increasing human activity with the onset of the Early Helladic (5000 BP) (WiLliams, 2004). A short lived phase of lagoonal predominance between 4000 and $4100 \mathrm{cal}$ BP could be the result of a proposed climate anomaly around 4200 BP creating cool and dry conditions (Mayewski et al., 2004) and hence hampering sediment dynamics and the consolidation of the barrier allowing salt water intrusion. However, the event-like character of the so-called $4.2 \mathrm{ka}$ event is controversial (FINNÉ et al., 2011). The reestablishment of marginal conditions and the gradual transition to fully terrestrial conditions starts around 4000 cal BP contemporaneously to the onset of the Middle Helladic $(2000 \mathrm{cal}$ BC). In this period, the first peak of settlement activity was reached as verified by an increased number of sites (Williams, 2004). A palynological signal of anthropogenic landscape modification displaying peaks in indicators of agriculture and stockbreeding appears in the Kotychi area in early Helladic times and thereby supports the archaeological evidence of increased human activity. The cultivation of Olea assigned to $3810 \mathrm{cal} \mathrm{BP}$ is an additional indicator for progressive human interference into nature (LAZAROVA, Koutsios \& Kontopoulos, 2012). Further, abundant charcoal fragments clustering between 3500 and 3600 cal BP might indicate human induced fire activity in the hinterland but could also be the result of natural fire activity. However, apparently rising demographic pressure resulted in forest clearing and overgrazing irrevocably destroying endemic vegetation. Devoid of its natural, protective cover, the soil was susceptible to erosion, which translated in silting up of lowlands ( $c f$. Dusar et al., 2011) and the development of a broad floodplain prograding into the lagoon (unit 13). Hence, it must be considered that the cessation of the waterlogged conditions at the end of stage 4 is attributed to human induced soil erosion providing a surplus of sediments.

The erosional force of a meandering river channel deeply incised into the floodplain eroded the sedimentary evidence deposited after 3500 cal BP. Accordingly, no statements about this period can be derived from the sedimentary sequence KOT3.

In summary, it is hypothesized that after the deceleration of sea level rise the influence on coastal evolution of variables such as anthropogenic induced hinterland erosion or climatic factors became more important. With a multiplicity a factors acting upon coastal morphology unstable environmental conditions in the coastal area prevailed.

\section{Summary and conclusion}

The sedimentary sequence of KOT3 provides insights into the evolution of the north Elean coastline from around 8500-3500 cal BP. Combining geochemical and sedimentlogical methods (XRF, grain size, OC, IC, and $\mathrm{C} / \mathrm{N}$ analysis) with Bayesian age-depth-modeling, four evolutionary stages documenting the transition from a marine to a marginal lagoonal environment could be identified. With regards to the driving forces of Holocene coastal evolution, this study demonstrates that Elis shows a two-phase development as reported from lagoons throughout the Mediterranean. Temporal analogies in coastal evolution across the Mediterranean indicate that early Holocene morphology results from the global aftermath of postglacial sea level rise. With vanishing of the ice sheets, the so far preeminent role of the eustatic signal was overwhelmed giving local and regional processes an accentuated role. Geomorphological instability in the coastal area indicates that a multiplicity of factors is acting upon morphology demanding constant adjustment. Hence, in mid to late Holocene natural and/or anthropogenically controlled sediment supply which translated in rapid morphological adjustment of the coastline was the driving force of coastal evolution.

In this study the application of the fast, non-destructive, high-resolution XRF-analysis technique proved to be a powerful tool providing a general overview of the chemical composition and altering element concentrations in a sedimentary sequence. The XRF-technique is a low-cost approach to discriminate marine and terrestrial environments and is especially useful when the concentration/preservation of indicative microorganism is poor or too time-consuming (e.g. Cundy et al., 2006). However, the semi-quantitative nature of the XRF-results needs to be kept in mind to avoid overinterpretation of the element concentrations.

Despite its potential to answer an array of palaeoenvironmental questions, deciphering sedimentary sequences in coastal environments presents certain pitfalls. Disentangling the superimposing, driving forces of coastal evolution is challenging and requires an independent chronology of involved processes to support their identification in the sedimentary sequence. Using neighboring cores as validation is restricted due to the rapid re-deposition and reorganization of unconsolidated sediments in the transitional zone where 
rivers and the sea merge. Another crucial point when studying lagoonal environments is the accuracy of radiocarbon dating, which is limited by a hardly quantifiable reservoir correction and re-deposited organic material. Chronological control is additionally hindered in tectonic active regions, where crustal movement might introduce uncertainties in age depth relation of the sediments.

Hence, the interplay of tectonic, sea level changes, human and natural induced changes of sediment budgets presents a challenge when deciphering sedimentary sequences in tectonic active coastal regions. Despite all that, the present study successfully demonstrate that Holocene coastal evolution of the North Elean coast shows significant analogies to circum-Mediterranean lagoon formation during the Holocene.

\section{Acknowledgements}

Special thanks are given to our colleagues from the Geological Institute of the University of Patras (Pavlos Avramidis, Kimon Christanis, Eleni Zagana) for their precious help. Thanks to Manfred Beckers and Sophia Dazert for help with lab and preparation work and further to Mathias Bahns, Görkim Oskay, Giorgos Savalas, Giorgos Floros, and Stavros Vrachliotis for great assistance during fieldwork. This project was founded by the Graduate School Human Development in Landscapes, Kiel University.

\section{References}

Avramidis, P., Bouzos, D., Antoniou, V. \& Kontopoulos, N. (2008): Application of grain size trend analysis and spatio-temporal changes of sedimentation, a tool or lagoon management. Case study: the Kotychi lagoon (western Greece). - Geologica Carpathica, 59 (3): 261-268.

Avramidis, P., Geraga, M. Lazarova, M. \& Kontopoulos, N. (2012): Holocene record of environmental changes and palaeoclimatic implications in Alykes Lagoon, Zakynthos Island, western Greece, Mediterranean Sea. - Quaternary International. DOI:10.1016/j.quaint.2012.04.026

Bao, R., Freitas, M.C. \& Andrade, C. (1999): Separating eustatic from localenvironmental effects: a Late Holocene record of coastal change in Albufeira Lagoon, Portugal. - The Holocene, 9: 341-352.

Bao, R., Alonso, A., Delgado, C. \& Pages, J.L. (2007): Identification of the main driving mechanisms in the evolution of a small coastal wetland (Traba, Galicia, NW Spain) since its origin $5700 \mathrm{cal}$ yr BP. - Palaeogeography, Palaeoclimatolology, Palaeoecology, 247: 296-312.

Bar-Matthews, M., Ayalon, A., Gilmour, M., Matthews, A. ¿ HawkesWORTH, C.J. (2003): Sea-land oxygen isotopic relationships from planktonic foraminifera and speleothems in the Eastern Mediterranean region and their implication for paleorainfall during interglacial intervals. - Geochimica et Cosmochimica Acta, 67: 3181-3199.

Bertrand, S., Sterken, M., Vargas-Ramirez, L., De Batist, M., Vyverman, W., Lepoint, G. \& FAGEL, N. (2010): Bulk organic geochemistry of sediments from Puyehue Lake and its watershed (Chile, $\left.40^{\circ} \mathrm{S}\right)$ : Implications for paleoenvironmental reconstructions. - Palaeogeography, Palaeoclimatology, Palaeoecology, 294: 56-71.

BoyLE, J.F. (2001): Inorganic geochemical methods in paleolimnology. - In: LAST, W.M. \& SMOL, J.P. (eds.): Tracking Environmental Change Using Lake Sediments, Vol. 2, Physical and Geochemical Methods: 83-142; Dordrecht (Kluwer Academic Publishers).

Brauer, A. (2004): Annually laminated lake sediments and their palaeoclimate relevance. - In: Fischer, H., Kumke, T., Lohmann, G., Flöser, G., Miller, H., von Storch, H. \& Negendank, J.F.W. (eds.): The Climate in Historical Times. Towards a Synthesis of Holocene Proxy Data and Climate Models: 109-128; Berlin (Springer Verlag).

Bronk RAmsey, C. (2001): Development of the radicocarbon calibration program. - Radiocarbon, 43: 355-363.

Bronk RAmsey, C. (2008): Deposition models for chronological records. Quaternary Science Reviews, 27: 42-60.

Bronk Ramsey, C. (2009): Dealing with outliners and offset in radiocarbon dating. - Radiocarbon, 51 (3): 1023-1045.
Burnett, A.P., Soreghan, M.J., Scholz, C.A. \& Brown, E.T. (2011): Tropical East African climate change and its relation to global climate: A record from Lake Tanganyika, Tropical East Africa, over the past 90+ kyr. - Palaeogeography, Palaeoclimatology, Palaeoecology, 303: 155-167.

Burtona P.W., Xua Y., Qina C., Tselentis G. \& Sokos E. (2004): A catalogue of seismicity in Greece and the adjacent areas for the twentieth century. - Tectonophysics, 390: 117-127.

Cohen, A.S. (2003): Paleolimnology. The History and Evolution of Lake Systems. - Oxford University Press, Oxford.

Cooper, J.A.G. (1994): Lagoons and microtidal coasts. - In: CARTER, R.W.G. \& Woodroffe, C.D. (eds.): Coastal Evolution. Late Quaternary Shoreline Morphodynamics: 219-265; Cambridge (Cambridge University Press).

Costas, S. \& Alejo, I. (2007): Local and global influences on the evolution of a transgressive sand barrier: Cíes Barrier, Northwest Spain. - Journal of Coastal Research, 50: 1121-1125.

Costas, S., Muñoz Sobrino, C., Alejo, I. \& Pérez-Arlucea, M. (2009): Holocene evolution of a rock-bounded barrier-lagoon system, Cíes Islands, NW Iberia. - Earth Surface Processes and Landforms, 34: 15751586.

Cundy, A.B., Sprague, D., Hopkinson, L., Maroukian, H., Gaki-Papanastassiou, K., Papanastassiou, D., Frogley, M.R. (2006): Geochemical and stratigraphic indicators of late Holocene coastal evolution in the Gythio area, southern Peloponnese, Greece. - Marine Geology, 230 (3-4): 161-177.

Curtius, E. (1851): Peloponnesos: eine historisch-geographische Beschreibung der Halbinsel, Band 1. - 495 p.; Gotha.

Cuven, S., Francus, P. \& Lamoureux, S. (2011): Mid to Late Holocene hydroclimatic and geochemical records from the varved sediments of East Lake, Cape Bounty, Canadian High Arctic. - Quaternary Science Reviews, 30: 2651-2665.

DEAN, W. (1999): The carbon cycle and biochemical dynamics in lake sediments. - Journal of Paleolimnology, 21: 375-393.

Dinis, J., Henriques, V., Freitas, M., Andrade, C. ¿ Costa, P. (2006): Natural to anthropogenic forcing in the Holocene evolution of three coasta lagoons (Caldas da Rainha valley, western Portugal). - Quaternary International, 150: 41-51.

DoukAKIs, E. (2003): The potential consequences of climate change on Kotychi Lagoon. - In: LEKKAs, T.D. (ed.): Proceedings of the 8th International Conference on Environmental Science and Technology. Lemnos Island, Greece, 8 - 10 September 2003. Full paper Vol A: 170-175.

Dusar, B., Verstraeten, G., Notebaert, B. \& Bakker, J. (2011): Holocene environmental change and its impact on sediment dynamics in the Eastern Mediterranean. - Earth Science Reviews, 108: 137-157.

Dypvik, H. \& Harris, N.B. (2001): Geochemical facies analysis of finegrained siliciclastics using $\mathrm{Th} / \mathrm{U}, \mathrm{Zr} / \mathrm{Rb}$ and $(\mathrm{Zr}+\mathrm{Rb}) / \mathrm{Sr}$ ratios. - Chemical Geology, 181: 131-146.

Eusterhues, K., Lechterbeck, J., Schneider, J. \& Wolf-Brozio, U. (2002) Late- and Post-Glacial evolution of Lake Steisslingen (I). Sedimentary history, palynological record and inorganic geochemical indicators. - Palaeogeography, Palaeoclimatology, Palaeoecology, 187 (3-4): 341-371.

Finné, M., Holmgren, K., Sundqvist, H.S., Weiberg, E. ひ Lindblom, M. (2011): Climate in the eastern Mediterranean regions, during the past 6000 years a review. - Journal of Archaeological Science, 38: 3153-3173.

Freitas, M.C., Andrade, C., Rocha, F., Tassinari, C., Munhá, J.M., Cruces, A.,Vidinha, J. \& Da Silva, C.M. (2003): Lateglacial and Holocene environmental changes in Portuguese coastal lagoons 1: the sedimentological and geochemical records of the Santo André coastal area. - The Holocene, 13: 433-446.

Fouache, E., Ghilardi, M., Vouvalidis, K., Syrides, G., Styllas, M., KuNESCH, S. \& STIROS, S. (2008): Contribution on the Holocene Reconstruction of Thessaloniki Coastal Plain, Greece. - Journal of Coasta Research, 24: 1161-1173.

Fountoulis, I., Vassilakis, E., Mavroulis, S., Alexopoulos, J. ひ ErkeKi, A. (2011): Qunatification of river valley major diversion impact at Kyllini coastal area (W. Peloponnesus, Greece) with remote sensing techniques. - In: Grützner, C., Pérez-López, R., Fernández Steeger, T., Papanikolaou, I., Reicherter, K., Silva, P.G. \& Vött, A. (eds.) Earthquake Geology and Archaeology. Science, Society and Critical Facilities: 42-45; Proceedings Vol. 2, 2nd INQUA-IGCP 567 International Workshop on Active Tectonics, Earthquake Geology, Archaeology and Engineering, 19.-24.09.2011, Corinth (Greece).

Goff, J., Chagué-Goff, C., Nichol, S., Jaffe, B. \& Dominey-Howes, D. (2012): Progress in palaeotsunami research. - Sedimentary Geology, 243-244: 70-88. 
Hodell, D. A., Channell, J. E. T., Curtis, J. H., Romero, O. E. \& Röhl, U. (2008): Onset of "Hudson Strait" Heinrich events in the eastern North Atlantic at the end of the middle Pleistocene transition (640 ka)?. Paleoceanography, 23: PA4218. DOI:4210.1029/2008PA001591.

Institute of Geology and Mineral Exploration (IGME) (1977): Geological Map of Greece, sheet Nea Manolas, scale 1: 50,000, Athens, Greece

Institute of Geology and Mineral Exploration (IGME) (1977): Geological Map of Greece, sheet Amalias, scale 1: 50,000, Athens, Greece.

Jacobshagen, V. (1986): Geologie von Griechenland. - Berlin (Gebrüder Borntraeger).

Jalut, G., Dedoubat, J.J., Fontugne, M. \& Otto, T. (2009): Holocene circum-Mediterranean vegetation changes: climate forcing and human impact. - Quaternary International, 200: 4-18.

Koinig, K.A., SHotyk, W., Lotter, A.F., Ohlendorf, C. ש Sturm, S. (2003): 9000 years of geochemical evolution of lithogenic major and trace elements in the sediment of an alpine lake: the role of climate, vegetation and land-use history. - Journal of Paleolimnology, 30: 307-320.

Kontopoulos, N. \& Avramidis, P. (2003): A late Holocene record of environmental changes from the Aliki lagoon, Egion, North Peloponnesus, Greece. - Quaternary International, 111: 75-90.

Kontopoulos, N. \& Koutsios, A. (2010): A late Holocene record of environmental changes from Kotihi lagoon, Elis, northwest Peloponnesus, Greece-- Quaternary International, 225: 191-198.

Kraft, J.C., RAPP, G., Gifford, J.A. \& Aschenbrenner, S.E. (2005): Coastal change and Archaeological setting in Elis. - Hesperia, 74: 1-39.

Kylander, M.E., Ampel, L., Veres, D. \& Wohlfarth, B. (2011): High-Resolution XRF Core Scanning Analysis of Les Echtes (France) Sedimentary Sequence: New Insights from Chemical Proxies. - Journal of Quaternary Science, 26: 109-117.

LAmbeck, K. \& Purcell, A. (2005): Sea-level change in the Mediterranean Sea since the LGM: model predictions for tectonically stable areas. Quaternary Science Reviews, 24: 1969-1988.

Lambeck, K., Woodroffe, C.D., Antonioli, F., Anzidei, M., Roland, W., Laborel, J. \& Wright, A.J. (2010): Paleoenvironmental Records, Geophysical Modeling, and Reconstruction of Sea-Level Trends and Variability on Centennial and Longer Timescales. - In: $\mathrm{CHuRch}$, J. A. Woodworth, P.L., Aarup, T. \& Wilson, W.S. (Eds.): Understanding Sea-Level Rise and Variability. - 61-121; Oxford UK (Wiley-Blackwell)

LAST, W.M. (1994): Deep-water evaporate mineral formation in lakes of Western Canada. - In: Renaut, R.W. \& LAst, W.M. (eds.): Sedimentology and Geochemistry of Modern and Ancient Saline Lakes: 51-59; Society for Sedimentary Geology, Special Publication, 50.

Lazarova, M., Koutsios, A. $\mho$ Kontopoulos, N. (2012): Holocene vegetation history of the Kotihi lagoon (northwest Peloponnesus, Greece). Quaternary International, 261: 138-145.

LEsPEZ, L. (2003): Geomorphic responses to long-term land use changes in eastern Macedonia (Greece). - Catena, 51: 181-208.

Löwemark, L., Chen, H.-F., Yang, T.-N., Kylander, M., Yu, E.-F., Hsu, Y. W., LeE, T.-Q., Song, S.-R. \& JaRvis, S. (2011): Normalizing XRF-scanner data: A cautionary note on the interpretation of high-resolution records from organic-rich lakes. - Journal of Asian Earth Sciences, 40 (6): $1250-1256$

Maroukian, H., Gaki-Papanastassiou, K., Papanastassiou, D. \& Palyvos, N. (2000): Geomorphological observations in the coastal zone of the Kyllini Peninsula, western Peloponnesus, Greece and their relation to the seismotectonic regime of the area. - Journal of Coastal Research, 16 (3): 853-863.

McManus, J. (2002): Deltaic response to changes in river regimes. - Marine Chemistry, 79: 155-170.

Meyers, P.A. ¿ LALLIER-Vergès, E. (1999): Lacustrine sedimentary organic matter records of Late Quaternary paleoclimates. - Journal of Paleolimnology, 21: 345-372.

Mingram, J., Negendank, J., Brauer, A., Berger, D., Hendrich, A., KÖHLER, M. \& UsINGER, H. (2007): Long cores from small lakes - recovering up to $100 \mathrm{~m}$-long lake sediment sequences with a high-precision rod-operated piston corer (Usinger-corer). - Journal of Paleolimnology, 37: 517-528.

Mook, W.G., \& van Der Plicht, J., (1999). Reporting ${ }^{14} \mathrm{C}$ activities and concentrations. - Radiocarbon, 41: 227-239.

Morton, R.A., Gelfenbaum, G. \& Jaffe, B.E. (2007): Physical criteria for distinguishing sandy tsunami and storm deposits using modern examples. - Sedimentary Geology, 200: 184-207.

Mügler, I., Gleixner, G., GÜnther, F., MäUsbacher, R., Daut, G., Schütt. B., Berking, J., Schwalb, A., Schwark, L., Xu, B., Yao, T., Zhu, L. \& YI C. (2010): A multi-proxy approach to reconstruct hydrological changes and Holocene climate development of Nam Co, Central Tibet. - Journal of Paleolimnology, 43 (4): 625-648.
Pavlopoulos, K., Karkanas, P., Triantaphyllou, M., Karymbalis, E. Tsourou, T. \& Palyvos, N. (2006): Palaeoenvironmental evolution of the coastal plain of Marathon, Greece, during the Late Holocene: Deposition environment, climate and sea-level changes. - Journal of Coastal Research, 22 (2): 424-438.

Philippson, A. (1959): Die griechischen Landschaften: Der Peloponnes, Band 2, Der Westen und Süden der Halbinsel. - Frankfurt (Klostermann).

Plater, A.J. \& Kirby, J.R. (2011): Sea-Level Change and Coastal Geomorphic Response. - In: WolAnski, E. \& McLusky, D.S. (eds.): Treatise on Estuarine and Coastal Science: 39-72; Waltham (Elsevier Academic Press).

Poulos, S.E., Voulgaris, G., Kapsimalis, V., Collins, M. \& Evans, G. (2002): Sediment fluxes and the evolution of a riverine-supplied tectonically-active coastal system: Kyparissiakos Gulf, Ionian Sea (eastern Mediterranean). - In: LonEs, S.J. \& Frostick, L.E. (eds.): Sediment Flux to Basins: Causes, Controls and Consequences: 247-266; Geological Society, London, Special Publications 191

R Development Core Team (2011): R: A Language and Environment for Statistical Computing, Version 2.13.2. R Foundation for Statistical Computing, ISBN 3-900051-07-0.

RAPHAEL, C.N. (1973): Late Quaternary changes in coastal Elis, Greece. Geographical Review, 63: 73-89.

RAPHAEL, C.N. (1978): The erosional history of the plain of Elis in the Peloponnesus. - In: BrICE, W.C. (ed.): The Environmental History of the Near and Middle East since the Last Ice Age: 51-66; London (Academic Press).

Reimer, P.J., Baillie, M.G.L., Bard, E., Bayliss, A., Beck, J.W., Bertrand, C.J.H., Blackwell, P.G., Buck, C.E., Burr, G.S., Cutler, K.B., DAmon, P.E., Edwards, R.L., Fairbanks, R.G., Friedrich, M., GuIlderson, T.P., Hogg, A.G., Hughen, K.A., Kromer, B., McCormac, G., Manning, S.W., Ramsey, C.B., Reimer, R.W., Remmele, S., Southon, J.R., Stuiver, M., Talamo, S., Taylor, C.B., Plicht, J.V.D. \& Weyhenmeyer, C.E. (2004): IntCal04 terrestrial radiocarbon age calibration, 0-26 cal kyr BP. - Radiocarbon, 46 (3): 1029-1058.

Richter, T.O., van der GaAst, S., Koster, B., VaArs, A., Gieles, R., DE Stigter, H.C., DE HaAs, H. \& van WeEring T.C.E. (2006): The Avaatech XRF Core Scanner: Technical description and applications to NE Atlantic sediments. - In: Rothwell, R.G. (ed.): New Techniques in Sediment Core Analysis: 39-50; Special Publication Geological Society, 267.

Roberts, N., Reed, J.M., Leng, M.J., Kuzucuoglu, C., Fontugne, M., Bertaux, J., Woldring, H., Bottema, S., Black, S., Hunt, E. \& KarabiyiKOGLU, M. (2001): The tempo of Holocene climatic change in the eastern Mediterranean region: new high-resolution crater-lake sediment data from central Turkey. - The Holocene, 11: 721-736.

Schofield, J.E., Edwards, K.J., Mighall, T.M., Martínez Cortizas, A., RoDRíGUEz-RACEDO, J. \& COOK, G. (2010): An integrated geochemical and palynological study of human impacts, soil erosion and storminess from southern Greenland since c. AD 1000. - Palaeogeography, Palaeoclimatology, Palaeoecology, 295: 19-30.

Siani, G., Paterne, M., Arnold, M., Bard, E., Métivier, B., Tisnerat, N. ש BAssinot, F. (2000): Radiocarbon reservoir ages in the Mediterranean Sea and Black Sea. - Radiocarbon, 42 (2): 271-280.

StANLEY, D.J. \& WARNE, A.G. (1994): Worldwide initiation of holocene marine deltas by deceleration of sea-level rise. - Science, 265: 228-31.

Striewski, B., Mayr, C., Flenley, J., Naumann, R., Turner, G. \& Lücke, A. (2009): Multi-proxy evidence of late Holocene human-induced environmental changes at Lake Pupuke, Auckland (New Zealand). - Quaternary International, 202: 69-93.

UnderhILL, J. (1988): Triassic evaporites and Plio-Quaternary diapirism in western Greece. - Journal of the Geological Society of London, 145: 269-282.

Vӧтт, A. (2007): Relative sea level changes and regional tectonic evolution of seven coastal areas in NW Greece since the mid-Holocene. - Quaternary Science Reviews, 26 (7-8): 894-919.

Vött, A., Fischer, P., Hadler, H., Handel, M., Lang, F., Ntageretzis, K. \& WillershäUSER, T. (2011): Sedimentary burial of ancient Olympia (Peloponnese, Greece) by high-energy flood deposits - The Olympia Tsunami Hypothesis. - In: Grützner, C., Pérez-Lopez, R., Fernández Steeger, T., Papanikolaou, I., Reicherter, K., Silva, P.G. ¿ Vött, A. (eds.): Earthquake Geology and Archaeology: Science, Society and Critical facilities. Proceedings of the 2 nd INQUA-IGCP 567 International Workshop on Active Tectonics, Earthquake Geology, Archaeology and Engineering, 19-24 September 2011, Corinth (Greece): 259-262.

Williams, E.L. (2004): Archaeological Explorations in Elis. A Diachronic Study of the Alpheios River Valley with a Catalogue of Material From Jerome Sperling's 1939 Survey. Master's Thesis. University of Cincinnati. Wright, K. (2011): Corrgram Package, Version 1.1 